\title{
The Amish Settlement in Honduras, 1968-1978: A (Half) Failed Attempt to Develop an Amish Understanding of Mission
}

\author{
Cory $^{1}$ and Jennifer Anderson \\ Visiting Assistant Professor of Sociology and Geography \\ Department of Society and Environment \\ Truman State University
}

\begin{abstract}
For their several-hundred years of successfully maintaining Amish settlements in North America, for what reason would a group of families - largely from Nappanee, IN, and Aylmer, ON—want to start a settlement in Honduras? This account traces the genesis of this Latin American settlement to the mid-century restlessness among Old Order Amish for religious and moral reform. The account especially follows families from Daviess County, IN, who, after failed settlement attempts in Michigan and Ohio, helped found Aylmer, ON, a successful revisionist Amish settlement. From there, Peter Stoll, one of the Aylmer founders, desired to move to Honduras for two reasons: (1) to provide an Old Order-style mission to people in a developing country, and (2) to escape the social and political changes of North America weighing on the Amish church. An Old Order idea of mission like Stoll's is to match the specific, nuanced practices of one's church with specific needs of another people, then move among the people and live out an alternative. Such a model reinforces the church's distinct practices. This contrasts with evangelical mission, which prioritizes saving souls over all else, including cumbersome "cultural" practices. Peter Stoll's clan was joined by estranged families from Nappanee. These eventually pushed for an evangelical outlook on mission and a lowering of Amish church requirements, solidifying among Peter's children a commitment to Old Order ideas - after years of grappling with the instability of reforming it — and a commitment to the Aylmer settlement, to which they returned.
\end{abstract}

\section{Keywords}

Guaimaca, Honduras, Amish settlement; Aylmer, ON, Amish settlement; Nappanee, IN, Amish settlement; Pike County, OH, Amish settlement; Peter Stoll; evangelical mission; New Order Amish; adoption; agricultural development; Amish mission movement; pure church movement

\section{Acknowledgements}

An expression of gratitude is due first to the three authors who lived in Honduras and unveiled much of their experiences during that time in print: Joseph Stoll, Monroe Hochstetler, and Jerry Eicher. Much appreciation is also expressed to the Heritage Historical Library for providing access to years of materials pertaining to the Honduras Amish settlement.

Anderson, Cory, and Jennifer Anderson. 2016. "The Amish Settlement in Honduras: A (Half) Failed Attempt to Develop an Amish Understanding of Mission." Journal of Amish and Plain Anabaptist Studies 4(1):1-50. 


\section{Introduction}

"In our trip to $\mathrm{C}$ [entral] $\mathrm{A}$ [merica] we spent several days in Honduras. What a pleasant surprise! We liked Honduras," exclaimed New Order Amishman Lester Beachy after visiting the Guaimaca Amish settlement. But it wasn't the Amish people that Beachy liked, for when he wrote these reflections in The Budget in 2001, he was nearly three decades too late to meet any.

We stood on the hill where the church house used to stand. We saw the tombstone of the 2 Amish that lie buried there. We saw where the Amish homesteads used to be. I tried to picture the scene several decades before when the Amish lived, toiled, and worshipped there. My heart was touched and I grieved to think that it is so sad not to have an Amish community in Honduras. ${ }^{1}$

The Honduras Amish settlement lasted around a decade, from 1968 to 1978 when the remaining families adopted automobiles, moving toward affiliation with the Amish-Mennonites. Realistically, though, could a Latin American horse-and-buggy Amish settlement really work? Could Amish establish a thriving settlement outside their North American homeland? And what hurdles, both from without and from within, would they have to cross to make it work? Were the Amish even of any use to the people among whom they lived in Guaimaca?

"I am about convinced that the Amish are better fitted to work for the well-being of these people than we are," wrote an Amish-Mennonite minister, who lived for a short time at the Guaimaca church a decade after the Amish left.

Our trucks and other modern conveniences that we use have a very strong attraction for these people [...] I fear it could lead to serious problems ahead. [...] This brings me to my main thought. I believe the Amish are better prepared to bring the Bible message [...] to the poor people of the earth than any other people [...] They need someone who will live the Bible right among them. Someone who will work and share without so many modern things to attract their minds and distract their hearts from that way of life which they can provide here. ${ }^{2}$

To this statement - given the chance to tour internationally - many Amish may agree. However, numerous hurdles stand before the Amish to make it happen, not the least of which are theologies and philosophies of mission which undercut the many minute Amish practices that even make it possible to live near the level of the people in impoverished areas. But is mission always destined to undercut Amish practice? Or is it just a certain kind of mission? Is there a uniquely Old Order Amish expression of mission to be salvaged from the pieces of the failed Honduras

\footnotetext{
${ }^{1}$ Lester Beachy, "Lyndonville, N.Y.,” The Budget, June 20, 2001. Clipping from Heritage Historical Library (HHL) Honduras box.

${ }^{2}$ Jacob Byers to Joseph Stoll, April 22, 1989. HHL Honduras box.
} 
settlement?

This article explores one of three Latin American countries that experienced an Amish settlement attempt in the $20^{\text {th }}$ century: Honduras. The Honduras settlement lends itself well to analysis, given that more has probably been written in retrospect about this settlement than any other extinct Amish settlement. The core body of literature - in addition to articles, letters, The Budget columns, and interview transcripts - are three autobiographies of the settlement: Joseph Stoll's Sunshine and Shadow (1996), Bishop Monroe Hochstetler's Life and Times in Honduras (2007), and Jerry Eicher's My Amish Childhood (2013), which this article critically analyzes as sources of primary data. ${ }^{3}$

\section{Laying the Groundwork for a Latin American Settlement}

The account of the Honduras Amish settlement, founded in 1968, has a distant genesis, going back to the religious upheavals among Amish and Old Order Mennonites characteristic of the post-World War II era. Inspired by the outgoing religiosity of mid-century conservative Mennonite periodicals and revival meetings and experiencing increased inter-settlement and inter-denominational contact through alternative service (C.P.S.) camps, many Old Order young men sought religious renewal within their own communities. Some viewed their communities as suffering from lackluster, even morally blighted where tobacco, bed courtship, and youth rowdyism were sanctioned as tradition. ${ }^{4}$ Even beyond these pinpointable causes and contentions, the more general mood of greater religious consciousness following history's most far-reaching war probably stirred the pot, as it did among many religions. ${ }^{5}$ The outcomes of this generation were multiple.

"During my stay in camp," wrote on young Amishman, "I had visited various Amish communities. Almost all of them had certain points I appreciated and wished our home community were like that, too. But we never had any thoughts that we would ever want to move to any of these." 6 Those very ponderings struck many young Amishmen, who were not ready to leave familiar structures and communities, yet wanted to see reforms. This heightened restlessness more often found resolve through new settlements and affiliations than it did in

\footnotetext{
${ }^{3}$ As an historic narrative, Eicher's book has been critiqued, given that he writes in a style reminiscent of his inspirational fiction books. As he takes some liberties, his book is best treated as lightly fictitious. For this reason, his account is used with caution for stand-alone historic facts but more freely for events and people verifiable in the other two autobiographies.

${ }^{4}$ Steve Nolt, "The Amish 'Mission Movement' and the Reformulation of Amish Identity in the Twentieth Century," Mennonite Quarterly Review 75, no. 1 (2001).

${ }^{5}$ In many unexplainable ways, the Amish and Old Order Mennonites are impacted by society's trends. For example, while historians and demographers often trace the 1950s baby boom to post-World War II eases and increases in household technology, the Amish had a parallel baby boom of their own, without GIs returning home and without improvements in household technology. See Martha J. Bailey and William J. Collins, "Did Improvements in Household Technology Cause the Baby Boom? Evidence from Electrification, Appliance Diffusion, and the Amish," American Economic Journal: Macroeconomics 3 3, no. 2 (2011).

${ }^{6}$ David Wagler, My Stretch in the Service (Civilian Public Service) and the Next Seven Years, vol. 2, Sunrise to Eventide (Aylmer, ON: Wagler Books, 2014), 208.
} 
redirecting a given settlement. Among these were not just the fellowship ${ }^{7}$ and New Order Amish ${ }^{8}$ movements - who partially relaxed restrictions and the weight of tradition to make room for reforms - but also Old Orders seeking reform within tradition, even intensifying tradition, a pure church movement. This movement sought intense community consciousness at an overt level (rather than as established across generations) as a necessary means to achieving congregational purity. $^{9}$

Renewal ideals struck pockets of Amish across the country, including Amish from Daviess County, IN, who eventually moved out. The recipe for migration from Daviess County included church turmoil, youth rowdiness, and several eccentric personalities. ${ }^{10}$ One personality was William Schrock, a transplant from the Shelbyville, IL, Amish-Mennonite church. Though seeking a stricter church setting than Shelbyville, Schrock took with him Shelbyville's adherence to the Spirit-inspired trance preaching of the late John Kauffman. ${ }^{11}$ Schrock's advocacy won some followers, among them being — albeit to varying degrees — the sons of Victor Stoll.

Some of the Stolls were similarly eccentric. Written accounts of several Stoll personalities across the generations range from gleaming to dismissive. If nothing else, they were (and still are) visionary. A critic describes the Daviess County patriarch as such:

[Victor] stirred always, and questioned everything. [...] [He] was estranged from the Amish church in Daviess when he died. [...]The Stolls are brilliant, on the math side of their brains. They can figure things out [but] they use those brains of theirs, as often as not, to dispute and argue. About the tiniest little silly things. How can the church rules be tweaked, so we're serving God better? What could we do, to suffer a bit more, so He'll be pleased? $^{12}$

Among the Stolls' endeavors across the generations are Pathway Publications, the defunct Cookeville, TN, experimental community, and the Caneyville Christian Community in Kentucky, a successor to Cookeville. That said, any family line mixes with other lines, and intermarriage with Waglers should not be overlooked; really, these two extended families produced some of the

\footnotetext{
${ }^{7}$ These were the churches started from the Amish mission movement that eventually adopted cars; their origin is in Holmes County. By the 1970s, many had merged with the Beachy Amish-Mennonites.

${ }^{8}$ Cory Anderson, "Retracing the Blurred Boundaries of the Twentieth-Century 'Amish Mennonite' Identity," Mennonite Quarterly Review 85, no. 3 (2011); Steve Nolt, "The Amish 'Mission Movement' and the Reformulation of Amish Identity in the Twentieth Century," ibid.75, no. 1 (2001); G.C. Waldrep, "The New Order Amish and Para-Amish Groups: Spiritual Renewal within Tradition," ibid.82, no. 3 (2008).

${ }^{9}$ Peter Hoover, "Pure Church Movement," (Detention River, Tasmania, Australia: Rocky Cape Christian Community, n.d.). Unpublished manuscript.

${ }^{10}$ Wagler, Stretch in the Service, 2, 209; James Stoll and Carolyn Stoll, The Road to Aylmer: Secrets of an Amish Life (Mr. James Stoll, 2014), 12-13.

${ }^{11}$ For background on John Kauffman and the Shelbyville Amish-Mennonites, see Harry H. Hiller, "The Sleeping Preachers: An Historical Study of the Role of Charisma in Amish Society," Pennsylvania Folklife 18, no. Winter (1968/69); Steven D. Reschly, The Amish on the Iowa Prairie: 1840-1910 (Baltimore, MD: Johns Hopkins University Press, 2000), Ch. 6.

${ }^{12}$ Ira Wagler, "The Sons of Albert Stoll," http://www.irawagler.com/?m=201406.
} 
more interesting personalities — and written about — among the Amish in the $20^{\text {th }}$ century.

In Daviess County, the Stolls' interest in Kauffman's teaching could have been the initial thrust into a generations-long quest for renewal and reform. Then again, Schrock may have just come at a time when the Stolls were seeking a script to flesh out their restlessness. Conflict within the settlement concerning a number of matters (among them William Schrock) prompted the migration of four Stoll siblings, including one minister, to southern Michigan in 1942-43. However, this move did not bring rest; not for them, not for Daviess County. In Daviess County, several divisions occurred in the late 1930s and through the 1940s, which included a short-lived second Amish affiliation, a Beachy Amish-Mennonite church, and a conservative Mennonite church. ${ }^{13}$ For the migrants, after a decade, they had twice vacated southern Michigan Amish settlements that shortly thereafter went extinct: Homer (1940-50) and Jerome (1945-56). ${ }^{14}$

Some from southern Michigan and others from Daviess County also attempted a settlement at Pike County, $\mathrm{OH}$, joining four Amish families with roots in Medford, WI, and Hartville, $\mathrm{OH}$, for a total of 43 individuals. ${ }^{15}$ The members declared their shared outlook in Ordnung of a Christian Church, an unusual act in that Ordnungs are usually not formally articulated, and even then, not in English. ${ }^{16}$ Tucked within more familiar Amish creeds and practices were tokens of the broader post-war renewal movement, declaring that they hold no fellowship with Amish who have "bed courtship, habitual smoking or drinking, old wives fables, non-assurance of salvation, anti-missionary zeal, or anything contrary to sound doctrine."17 Committed to this "missionary zeal," they used English instead of German when local visitors attended. ${ }^{18}$ Undoubtedly arousing the ire of some Old Order Amish, the Ordnung was nonetheless severe on other characteristically Amish stands, making clear their intention to not only remain Amish but to salvage good traditions from morally wayward settlements. ${ }^{19}$

In the last half of the written Ordnung document, the community rationalized the church's right to make standards. While their articulation was strikingly erudite, this selfreflection was hardly unique. It echoed many other small, scattered mid-century experimental movements that later coalesced into the Hoover Mennonites (Scottsville, KY), Orthodox

\footnotetext{
${ }^{13}$ Joseph Stoll, The Amish of Daviess County, Indiana (Aylmer, ON: Joseph Stoll, 1997), 106-08; Wagler, Stretch in the Service, 2, 202-05.

${ }^{14}$ David Luthy, The Amish in America: Settlements That Failed, 1840-1960 (Lagrange, IN: Pathway Publications, 1986), 202-07; Stoll, Amish of Daviess County, 106-08; Stoll and Stoll, Road to Aylmer, 15-16.

15 Albert Keim, "History of an Amish Community: Pike County, Ohio, 1949-1953" (Eastern Mennonite University, 1961), 7. Levi Slabaugh and Truman Helmuth came directly from Medford. Nicholas Stoltzfus had moved from Medford to Jerome, then to Piketon, along with Peter Stoll. Wagler, Stretch in the Service, 2, 232.

${ }^{16}$ Keim, “Amish: Pike County, Ohio," 1-2; Luthy, Settlements That Failed, 366-67; Wagler, Stretch in the Service, $2,235-36$.

17 “Ordnung of a Christian Church," (Piketon, OH: Pike County Amish Church, 1950), 3.

${ }^{18}$ Keim, "Amish: Pike County, Ohio," 7.

${ }^{19}$ Although they varied from several core Amish practices; they used English in services for visitors who could not understand German,
} 
Mennonites (Gorrie, ON), and Believers in Christ (Lobelville, TN), among others. ${ }^{20}$ Such ones subjected Old Order social and lifestyle practices to the scrutiny of the Bible and historic church writings, to the end of freeing the communally binding power of plain Anabaptist traditions from parasitic practices unworthily claiming the protection of "tradition."

The new Pike County settlement seemed to go well, although there is some indication of unrest (not surprising given the new trails they were blazing). ${ }^{21}$ Only about three years after settlement, the Pike County Amish learned that the government planned to construct a nuclear plant nearby. The thousands of workers it would bring to the area predestined the community to extinction. $^{22}$ In 1953, most families decided on a new home at Aylmer, ON. While only two families in Pike County were from the Daviess County group (David Wagler and Peter Stoll), Pike County, despite its brevity, was an important coalescing of visionaries that would help bring the Aylmer, ON, idea into fruition. Families from Daviess County, IN-including Bishop Peter Yoder who had provided oversight for Piketon and whose wife was of the Wagler clan - and southern Michigan joined them. All said and done, the founding Aylmer Amish settlement consisted of extended Wagler and Stoll families from Daviess County, IN, and several others they had befriended in their migrations. ${ }^{23}$ A decade of uncertainty and frequent movement - a result of a new vision they were still fleshing out - found new hope across an international border.

What pushed the group to look beyond America was state interference; among the most troubling were U.S. conscription, private school conflicts, and Social Security. ${ }^{24}$ They were pulled to Aylmer because of inexpensive farmland; conduciveness to small-scale, locally focused dairies; and few laws pertaining to farming, schooling, and national insurance. ${ }^{25}$ However, U.S. policies tarried only momentarily before following the Amish across the border. For one, the Canadian pension plan became compulsory in 1965. Seeking to defend their autonomy as religious communities, many plain Anabaptists refused to pay, including the Aylmer Amish. Within two years, the federal government was seizing milk checks and deducting payments from bank accounts, a shockingly invasive measure. ${ }^{26}$ Additionally, regional agriculture was

\footnotetext{
${ }^{20}$ For an elaboration on these movements, see Hoover, "Pure Church Movement."

${ }^{21}$ Wagler, "The Sons of Albert Stoll".

${ }^{22}$ Although church troubles may have scattered the group anyways; see ibid.

${ }^{23}$ Of note, the Noah Keim of Pike County, originally from Hartville, OH, could not enter Canada because of a handicapped daughter. He eventually settled among the Stuarts Draft, VA, Amish, and was central in an almost immediate division birthing a Beachy Amish-Mennonite church. Not satisfied with the half-way mission-oriented reforms of the new church, he led another group to Madison County, VA, where he helped established the most aggressively mission-minded Beachy church of the time. Some of the more surprising accommodations for mission programs at Pike County may have been his, and the Aylmer group was certainly able to more firmly ground their Old Order character without him. Anderson, "Blurred Boundaries," 376-77.

${ }^{24}$ Luthy, Settlements That Failed, 206-07,368-69; Wagler, Stretch in the Service, 2, 258-61.

${ }^{25}$ Stretch in the Service, 2, 264-65; Dennis Thomson, "Canadian Government Relations," in The Amish and the State, ed. Donald Kraybill (Baltimore: Johns Hopkins University Press, 1993), 236. Note: the Thomson chapter is only in the first edition.

${ }^{26}$ T.D. Regehr, "Relations between the Old Order Amish and the State in Canada," Mennonite Quarterly Review 69, no. 2 (1995); Thomson, "Canadian Relations."
} 
transitioning to a larger scale and the Amish were detecting hostility toward their operations, ${ }^{27}$ culminating in out-and-out conflict by the mid-1970s. ${ }^{28}$ Beyond these specific structural shifts, the Amish were feeling broader pressures from cultural changes, and they wanted to slow down the pace of life. ${ }^{29}$

\section{The Honduras Settlement Takes Root}

When talk of yet another migration started, the Aylmer settlement was barely a half generation old, and it was a very successful half-generation at that. Not only had they established what was fast becoming a widely known Amish publishing house - Pathway — but the community was continually adding migrants to its membership until their single district was full. Unlike older Amish settlements accustomed to managing growth through district division, such a mechanism was not yet a given for Aylmer Amish. And with a vision to engage their religion with broader society, migration to new non-Amish areas was a consistent response to growth. ${ }^{30}$ The fact that they had already been willing to sacrifice for their vision through costly migrations is not insignificant to their willingness to look at a more consequential border crossing.

Among Aylmer's members was Victor Stoll's son Peter, who had migrated four times in eleven years (his wife was a Wagler, sister to Bishop Peter Yoder's wife). Peter was a "warm and outgoing" man who "had a compassion for souls" and "got along with everyone, especially the non-Amish," "a real people person, perhaps a born salesman. [...] well known and well liked.",31 After his house burned to the ground in Aylmer in November 1966, some deep reflection may have struck him that intensified his mission efforts. ${ }^{32}$ He had already been "working with people at the margins" for several years, but in modest proportions. For instance, he had purchased a farm on the north coast of Lake Huron in 1962, where he spent winters providing training to Ojibwa people with the hope of eventually starting a children's home. ${ }^{33}$ A children's home would come to pass, but not in Canada. Peter's ambitions were turning global. He was well-read in world geography, especially Latin America, and corresponded with those of similar interest. ${ }^{34}$ Combined, these characteristics turned him into one of mid-century Amishdom's most visible mission advocates. As a grandson later wrote,

[Peter] took on bishops in his frequent complaints over the lack of missions and outreach.

\footnotetext{
${ }^{27}$ Joseph Stoll, Sunshine and Shadow: Our Seven Years in Honduras (Aylmer, ON: Joseph Stoll and Family, 1996), 15 .

${ }^{28}$ Regehr, "Amish and Canada."; Thomson, "Canadian Relations."

${ }^{29}$ Stoll, Sunshine, 13.

${ }^{30}$ Cory Anderson, "Religiously Motivated Migration," The Sociological Quarterly 57, no. 3 (2016): $387-414$.

${ }^{31}$ Quotes combined from interview with Vernon and Katie Schmucker (June 28, 2013), Guaimaca, Honduras; Stoll and Stoll, Road to Aylmer, 116; Richard A. Pride, "Elmo Stoll and the Christian Community at Cookeville," Border States: Journal of the Kentucky-Tennessee American Studies Association, no. 14 (2003): 38.

${ }^{32}$ Jerry Eicher, My Amish Childhood: A True Story of Faith, Family, and the Simple Life (Eugene, OR: Harvest House, 2013), 23-24.

${ }^{33}$ Pride, "Christian Community at Cookeville," 38; Stoll and Stoll, The Road to Aylmer: Secrets of an Amish Life, $171-72$

${ }^{34}$ Joseph Stoll, "How the Amish Chose Honduras [Part I]," Plain Interests, August 2005, 6. HHL Honduras box.
} 
Somehow he survived those clashes. Often during his lengthy exchanges with church authorities, he would say too much. But once his temper had cooled, he'd get into his buggy and make return trips to apologize. ${ }^{35}$

The opportunity to visit Latin America came when, in 1966, Peter's brother Albert Stoll, a minister, moved to Pilgrimage Valley, Belize, from the St. Joe, AR, settlement. St. Joe was a pure church effort that had blended Amish and Mennonite backgrounds, and the Belize settlement was a continuation of this vision. ${ }^{36}$ Pilgrimage Valley was not far from the Kleine Gemeinde Mennonites' Spanish Lookout colony. The Mennonites had only been cutting into the virgin wilderness for eight years, so the area was still relatively undeveloped and isolated, to the liking of the group. ${ }^{37}$ Members of Peter's family made several forays south of the border that year and into 1967, visiting and assisting Freundschaft with building homes. But in these visits, they also held an underlying goal: investigate how the pioneers fared and assess the prospect of a Central American home for himself. ${ }^{38}$

On both accounts, their goals were met. On one of the plane rides between, Ira, a son of Albert living in Aylmer, struck up a conversation with a Dr. Youngberg. ${ }^{39}$ Youngberg, a Seventh Day Adventist, oversaw a Honduran boarding home in Peña Blanca, Honduras, which is about a quarter of the 125 miles from San Pedro Sula on the northern coast to the inland capital Tegucigalpa. Around 80 children boarded there, yet the staff included only four North American women and several locals. Youngberg related how they "snatch starving babies from the brink of the grave and nurse them back to health with good nutrition." The Stolls were invited to visit. Even before they could make it there, Peter was already contemplating Honduras as an option during the summer of 1967. This was actually the second Latin American destination he was considering. Up to that time, he had been contemplating Paraguay, where Amish from a neighboring Ontario community were entertaining a move. ${ }^{40}$

In December 1967, a year after the invitation to visit, Peter took part of his family to the Youngberg home in Honduras. As Peter surveyed the home, he wrote that "[...] the tears came freely. They [...] turn down all but the most desperate cases." Wasting no time, Ira, accompanied by his cousins Mary and Sarah, returned in a month to help with the work. Ira's weekly letters to The Budget through the first half of 1968 procured enough support for him to direct the construction of a new children's home, not to mention a roofed-over play area. ${ }^{41}$ The three of them were also joined by two sisters and a cousin from Nappanee, IN, Lizzie and Erma Schmucker and Lydia Mae Hochstetler, as well as another young Amish woman, who all

\footnotetext{
${ }^{35}$ Eicher, Childhood, 9.

${ }^{36}$ Hoover, "Pure Church Movement."

${ }^{37}$ Heinrich Penner, John Reimer, and Leonard Reimer, eds., Spanish Lookout since 1958: Progress in Action (Spanish Lookout, Cayo, Belize: Spanish Lookout, 2008).

${ }^{38}$ Stoll, "Honduras I," 6.

${ }^{39}$ Ibid. Possibly a train trip, as our research notes have conflicting information, but plane seems more probable.

${ }^{40}$ Stoll and Stoll, Road to Aylmer, 191.

${ }^{41}$ Stoll, Sunshine, 58.
} 
responded to a request for further assistance from Youngberg printed in The Budget. ${ }^{42}$

Peter visited his children in Honduras, with the overarching goal of scouting out settlement prospects. Along the way, he met Texan investor Dan Foster. Foster flamed the fans of Peter's settlement ambitions. Honduras was not a fatalistically impoverished country, Foster told Peter, but rather a promising site for agricultural development. And Foster had the evidence to prove it: he had purchased 800 acres, employed locals to clear it, and then established a locallyoperated ranch with 500 cattle. The Amish could do the same, Foster nudged, and with the government's homestead offer in eastern Honduras - settle and develop the land and it is yours for free- the upfront cost will be much lower. ${ }^{43}$

Peter and Ira set off to the capital, Tegucigalpa, from which they took an eastern highway to the frontier. What they encountered there was every bit worth its price. But they had also passed through the village of Guaimaca, 60 miles east of the capital. "It is a very quiet area," Ira wrote in The Budget,

... and still in reach of the people and markets. This is a valley located in rolling pine hills with a big logging industry. It has a nice flowing river through it and good well water at $30 \mathrm{ft}$, which is rare in Honduras. It looks like an ideal spot for a thriving farming community. $^{44}$

So serendipity had finished her work, or at least pinpointed a destination. Now Peter had the more familiar task of convincing others to join him in this migration. But this was not Michigan, Ohio, or even Ontario - this was an unprecedented attempt to move horse and buggy Amish deep into Central America: a new climate, a new language, and a new culture. ${ }^{45}$

And yet the Aylmer Amish by-and-large preferred another destination, Prince Edward Island (an investigative party had found it "as nice as Lancaster Co"). At a meeting to discuss new settlement possibilities, Peter and Ira put Honduras on the table, arguing that Amish farmers are much more needed in Honduras, where children are going hungry, than in North America, where governments pay farmers not to farm. ${ }^{46}$ But the unfathomable distance and unfamiliar language and culture was nothing short of gambling with Amish untouchables: family relations, visiting patterns, the German language, ancestral farming techniques, and even the ingredients behind hearty Pennsylvania Dutch cooking. To move that far was to "cast out the old and proven ways, the familiar Ontario Amish setting, and recklessly [give themselves] into a terribly-

\footnotetext{
${ }^{42}$ Interview with Vernon and Katie Schmucker, June 28, 2013; Stoll, Sunshine.

43 Stoll "Honduras I," 7.

${ }^{44}$ As quoted in ibid.

${ }^{45}$ While a Mexican Amish settlement started in the 1920s, it was just across the Texas border, and while some Amish moved to Pilgrimage Valley, Belize, in the 1960s, they contained a mix of Mennonites, nixing the settlement as Amish.

${ }^{46}$ Stoll, "Honduras I," 7.
} 
faraway Unknown." ${ }^{47}$ Prince Edward Island trumped.

Notwithstanding their earlier enthusiasm, the investigative party's follow-up trip to Prince Edward Island was sullying. Summers were short and winters long, hard, cold, and damp, certainly not ideal for those prospective settlers with asthma and hay fever. On top of environmental factors were cultural; a news reporter described the islanders as clannish, who, with "their pitchforks [make] it their business to chase all foreigners off the island!" 48 Meeting again, the prospective migrants weighed the pros and cons of Prince Edward Island. Peter and Ira made their case again for Honduras. Prince Edward Island still prevailed. ${ }^{49}$

Peter and Ira could not go to Honduras alone; Amish settlements must replicate community, and, despite Peter's mission interests, that community must come from within or the community is simply not Amish. The Honduras idea having fallen on domestically inclined ears, Peter and Ira committed themselves to the Prince Edward Island effort, that is, until the very next day. ${ }^{50}$ Monroe Hochstetler, a transplant to Aylmer from Nappanee, IN, had just returned from a Northern Indiana funeral with news: Richard Hochstetler, a Nappanee minister, suggested that if Peters moved to Honduras, they would join him. "Peter literally jumped out of his chair [...]. 'They will?' He sank back down into his chair. 'That is almost too good to be true [...] If we have that kind of support, we will go." "51 It was not just Monroe, but, all said and done, included three more families, pulled in through family ties: minister Vernon \& Katie Schmucker with their nine children (Vernon's sisters Lizzie and Erma worked at the Youngberg home and, having returned home, encouraged Vernon to go to Honduras), ${ }^{52}$ Leroy \& Lydia Mae Hostetler with their nine (Vernon's and Leroy's wives were sisters), and Emil \& Edna Helmuth with their eight (Emil's and Monroe's wives were sisters) (see Appendix 2 for family lines).

And go Peter did! After a rendezvous in Nappanee with the interested parties, Peter sold out, farm, possessions, and most everything else. He kept back only a buggy, a sewing machine, and a few pieces of horse drawn equipment, which were sent to Honduras. ${ }^{53}$ While mission was certainly on his mind, he told reporters at the November sale that "[we] are leaving Canada because of government socialistic measures such as Canada Pension Plan and Medicare [...] Some of our people are in Costa Rica and they like it there." ${ }^{54}$ Indeed, feelings were running high among the Amish in North America during the late 1960s and early 1970s, as they faced one

\footnotetext{
${ }^{47}$ Stoll Sunshine, 13.

${ }^{48}$ This was certainly not the reception Amish scouts from Milbank / Milverton, ON, received in 2014, when they noted that the Islands were courteous and had a sense of humor. See Maureen Coulter, "Amish Communities Checking out Province," The Guardian, October 28, 2014.

${ }^{49}$ Joseph Stoll, "How the Amish Chose Honduras Part II," Plain Interests, September 2005, 10. HHL Honduras box.

${ }^{50}$ Ibid.

${ }^{51}$ Monroe Hochstetler, Life and Times in Honduras: Twenty Families Struggle in Honduras (Worthington, IN: Monroe Hochstetler, 2007), 4.

52 Interview with Vernon and Katie Schmucker.

${ }^{53}$ Stoll and Stoll, Road to Aylmer, 193.

${ }^{54}$ Stoll, "Honduras II," 10-11. In referring to "our people" in Costa Rica, he speaks of the Amish-Mennonites.
} 
government conflict after another. Many spoke of moving out of North America, ${ }^{55}$ although in the end, few acted. The Honduras pioneers included Peter, his wife Anna, and their unmarried children, Abner, Mark, Mary, Sarah, and David Fehr (a foster child). ${ }^{56}$ Within two months_-just over a year after he had first visited Honduras-Peter dropped his life savings into a 500 acre property just west of Guaimaca. $^{57}$

In Nappanee, the group joining Peter had already contemplated moving out of the settlement but did not have a destination selected. Just like in other long-standing Amish settlements across North America, this clique had found inspiration in the mid-century reform movement, exemplified in their stand against tobacco, use of evangelical key phrases like "new birth," the mixture of English into otherwise German preaching, and youth activities for "clean fun and reading the Bible." ${ }^{, 58}$ But unlike other Amish settlements, the Nappanee settlement never generated a reform-oriented schism. The local fellowship church (Berea), receiving a trickle of Amish, had actually divided from the (Old) Beachy church (Maple Lawn Amish-Mennonite), not the Amish, and a New Order movement never started. Migration was the preferred option. But where to? Peter's sonorous Honduran overtures to the tune of missions combined with the Nappanee group's Aylmer connection via Monroe Hochstetler provided the answer. They finally joined Peter in 1970, Monroe's and Emil's families in the spring (traveling separately), and Vernon's and Leroy's in the autumn. Although they shared Peter's outlook of a reformed church, they did not come with Peter's missionary zeal as much as simply came to get away. ${ }^{59}$

But the Nappanee families would not be enough. Soon after settling in, Peter wrote letter after letter to Aylmer, lobbying for more migrants. By this time, the Aylmer church and leadership had come to condone the de facto settlement, opening the way for others to join, ${ }^{60}$ although Bishop Peter Yoder quietly felt that " $[\mathrm{t}]$ his foreign mission outreach would not work.",61 Peter Stoll's married sons, Joseph, Deacon Stephen, and James had given their father a firm "no!" when he first suggested the Honduran venture; their wives' parents would oppose such distance from their daughters, they reasoned. Yet the tug of strong ties worked to Peter's advantage. When Peter took these men's unmarried brothers and sisters along, feelings of loss struck the brothers. "Gradually, slowly, little by little, circumstances have shifted our thinking," Joseph reflected in his journal the Sunday after selling out. ${ }^{62}$ Two others did not budge: James's wife was firmly against the move and daughter Martha needed to care for her husband's aging parents. ${ }^{63}$ Joseph and Stephen were not alone, though, in the tugging of being near family that

\footnotetext{
55 Joe Wittmer, “Cultural Violence and Twentieth Century Progress,” Practical Anthropology 18 (1971): 153-55.

${ }^{56}$ Eicher, Childhood, 27.

${ }^{57}$ Stoll, Sunshine, 12.

${ }^{58}$ Interview with Vernon and Katie Schmucker.

${ }^{59}$ Ibid.

${ }^{60}$ Hochstetler, Life and Times, 10; Eicher, Childhood, 27.

${ }^{61}$ Childhood, 48. This feeling may be overstated in Eicher's book, as Joseph Stoll noted in a letter to the authors that "this strong sentiment is news to me" (June 15, 2016).

${ }^{62}$ Stoll, Sunshine, 12.

${ }^{63}$ Stoll and Stoll, The Road to Aylmer: Secrets of an Amish Life, 192.
} 
was moving; Monroe Hochstetler, later reflecting on his wife's well-being in Honduras, wrote, "What is better than to have a sister close by to visit and share with when times become difficult and trying?"64

In January of 1969, Joseph Stoll, Monroe Hochstetler, and Peter's son-in-law Sammy Eicher went on a three week-long investigation trip. The bus ride to Guaimaca from the Tegucigalpa airport was four long and rough hours, but their spirits changed when they were dropped off. After a tour of Peter's farm and Guaimaca, the men bounced questions around about farming, political affairs, transportation, and logistics of adjusting. The trip also exposed them first-hand to the Honduran people, which they saw through a framing that helped to define their sense of mission: impoverished, hungry, and malnourished, "immense physical and spiritual needs" that "stirred the Amish men's souls, [...] the potential of what needed to be done and what could be done." All returned not only with positive reports but with a humanitarian burden. ${ }^{65}$ Sammy moved in July of 1969 while Joseph and Stephen moved in October; Monroe came the following spring. ${ }^{66}$

Peter relied on Nappanee and Aylmer families for the core group, but he also flung a fistful of darts into the air with his other miscellaneous letters to North America. Ira also appealed for more settlers to Guaimaca in his Budget letters, though he was still at the Youngberg home. Read widely, the letters and Budget columns nevertheless inspired more imaginations than migrations. David Peachey, of Selinsgrove, Pennsylvania, was an exception. He was particularly struck by a Family Life article of Joseph Stoll's that said Amish farmers were needed in undeveloped countries, where hunger remains a problem. He questioned Joseph out about the settlement in a December 1969 letter; evidently, Joseph answered well, as in January 1971, the Peachey family moved in. ${ }^{67}$

With the exodus to Honduras, the Prince Edward Island scheme was scuttled. But the Aylmer community was also hitting a generation-old growing pain. Minister Nicholas Stoltzfus, whose migrations had paralleled Peter's from southern Michigan to Pike County to Aylmer, had planned to go to Honduras, partly because his advocacy for allowing the moustache was not winning favor in Aylmer. He backed out and instead helped start a settlement in Punxsutawney, PA, in 1969, moving out of Aylmer with a separate group; ${ }^{68}$ the settlement was extinct by 1974 . In 1970, Bishop Peter Yoder moved out of Aylmer to southern Missouri-Marshfield — which itself went extinct in 1990. Still others went hither and yon from Aylmer, and yet others moved in to occupy the homes being sold, as with several families from Iowa. Bishop Yoder was replaced by Jacob Eicher in 1973 and, as the settlement expanded into more districts, Peter Stoll's son

\footnotetext{
${ }^{64}$ Hochstetler, Life and Times, 23.

${ }^{65}$ Eicher, Childhood, 27-31; Hochstetler, Life and Times, 5-11; Stoll, Sunshine, 13. Quotes from Eicher, Childhood, 31.

${ }^{66}$ Stoll, Sunshine, 19,24; Hochstetler, Life and Times, 16-18.

${ }^{67}$ Stoll, Sunshine, 47-50,57,74; Hochstetler, Life and Times, 65-67.

${ }^{68}$ Letter to authors from Joseph Stoll, June 15, 2016; Stoll and Stoll, The Road to Aylmer: Secrets of an Amish Life, $196-97$.
} 
Elmo joined Eicher in the bishophoric. These two would move the community toward a stricter Ordnung, and Elmo would increase the settlement's visibility through his writing, itinerant preaching, and dispute arbitration.

In summary, a number of small forces came together to establish a legitimate and even promising Amish community in Honduras. These included the chance actions of a charismatic leader (Peter Stoll) and the chance events encountered along his way; the restlessness among North American Amish created by the mid-century mission and pure church movements; alienation triggered by Western culture and growing state regulation; ties that connected Aylmer Amish — who hail from a variety of settlements - to other settlements where families were already pondering relocation; and family ties, the tug of living near Freundschaft.

It also should be noted that their migration came during a surge of a more general American and Canadian preoccupation with Latin American affairs, from political changeovers and economic development to Christian mission. The Amish were to meet many other North Americans during their stay in Honduras.

\section{Adjusting to Honduras and Adjusting Honduras to the Amish}

Unlike Beachy Amish-Mennonite efforts in neighboring Belize and El Salvador, the Guaimaca Amish settlement was not an arm of a North American-based mission program. Rather, it was an attempt to recreate a familiar ethno-religious social system in a place that would better benefit from it. In that sense, it mirrored Beachy colonization activity in Costa Rica and Paraguay. However, their concept of mission was still somewhat different from the Beachys, who consciously implemented evangelical tactics. The difference can be likened to the contrast between the Great Commission emphasis of the Beachys, to go and do, and the characteristically Old Order outlook of the City on the Hill metaphor, to go and be. In a diary entry, Joseph Stoll succinctly captures this self-reflective, yet still Old Order-style, mission outlook:

I'm convinced more than ever that Honduras needs an Amish settlement, both from the standpoint of what we could provide agriculturally and, more important, what we have to offer spiritually. These people deserve an Anabaptist-type witness. They are not used to seeing the Christian faith taken seriously. ${ }^{69}$ (emphasis added)

To recreate religious community and employ it in a self-consciously outreach-oriented way was one of the major thrusts of the emerging New Order Amish movement. Affirming Guaimaca's alignment with the New Orders - more incidentally in hindsight than by plan — was their choice of bishop oversight: the Hartville, Ohio-based bishop Wally Byler, who had provided assistance to the first New Order splinter district in Holmes County, OH, in 1966. An Aylmer leader-likely Bishop Peter Yoder-had worked with Wally Byler on an investigation committee

${ }^{69}$ Stoll, Sunshine, 51. 
prior to the division, so connections predated the Honduras settlement. ${ }^{70}$ Peter Yoder had declined to provide Honduras with bishop oversight, so on invitation from the Guaimaca settlement to assume that role, Byler made his first trip to Honduras in May 1970 just as the Indiana families were moving in. He conducted baptism, council meeting, and communion. ${ }^{71}$

The New Order movement resonated somewhat with the goals of the Honduras settlement, but the movement was too young and the Honduran experiment too new to tell for certain. In Ohio, the New Order movement was seeking revisions within the Old Order without going as far as the Amish-Mennonites had in technological and dress changes. Like the AmishMennonites, New Orders emphasized strict standards for youth gatherings and courtship, spontaneous articulation of one's spiritual state, and partial incorporation of evangelical Protestant programs, including Sunday school, Gospel hymn sings, and outreach. But would their mission outlook be something new, something characteristically Old Order, or would it be simply a borrowing of programs, modes, language, and emphases from the evangelicals. The future was as uncertain for the New Order Amish as the Guaimaca Amish on this point.

An additional indication of Guaimaca's leaning toward the ideas that the emerging New Order encapsulated was that many moved to Honduras using airplanes, a convenience Old Orders barred but New Orders accepted in the name of missions. ${ }^{72}$ At that time, airplanes only flew to Tegucigalpa from New Orleans and Miami, with stops on the way. ${ }^{73}$ Despite such limitations, air travel was relatively convenient when compared to boat or overland travel. The goal, however, of Guaimaca was not to "go New Order," and the exact relationship of this new movement with other Amish fellowship circles was unknown. What should be stressed here is that the ideals of the Honduras group resonated with a bishop who came to sympathize with what would eventually be the separate fellowship now called "New Order."

Recreating the religious community requires not only ceremonial and sacral legitimacy but also basic patterns of everyday activity. Although aware of obvious changes Honduras would demand, the Amish nonetheless frequently fell back on familiar modes and patterns of existence, excusing the differences between their modes and the patterns of locals as a matter of their means, their skills, and their money (they sometimes pondered whether the locals might even learn a thing or two from how they do things). Migrants shipped crates of North American rarities - a typical one weighing 2,700lbs and including 22 banana boxes among larger items ${ }^{74}$ to their Honduran address to replicate North American living patterns. A sample of their imports include a gas powered washing machine, a Ford 2701 diesel truck engine, an Electrolux kerosene-fueled fridge, a cream separator, an ensilage cutter, and the board games Monopoly and

\footnotetext{
${ }^{70}$ Edward Kline and Monroe Beachy, "History and Dynamics of the New Order Amish of Holmes County, Ohio," Old Order Notes, no. 18 (1998): 12.

${ }^{71}$ Stoll, Sunshine, $49,74$.

${ }^{72}$ Peter Stoll's family went overland and David Peachey's by boat from New York City. Hochstetler, Life and Times, 15,49,65; Stoll, Sunshine, 19.

${ }^{73}$ Eicher, Childhood, 179.

${ }^{74}$ Hochstetler, Life and Times, 54,386.
} 
Clue. $^{75}$

The first priorities were land and residences. As the earlier families arrived, some scouted through the local valley for land on which to build a home. When local landowners got wind of the immigration influx, they raised the prices (and the Amish balked). Ultimately, Peter subdivided Finca Sansón, his 550 acre lot purchased from a foreigner, into residential parcels. In early 1971, the community acquired the adjoining 450 acre farm, La Granja, ${ }^{76}$ making for "a fairly close neighborhood" 77 colony-style. The properties were at the base of a 7,500 foot mountain and had creeks. ${ }^{78}$ Upon their lots the Amish families built wooden houses; most of the locals used adobe, which the Amish assumed was because of poverty. While adobe was certainly cheaper, it also did not attract termites! (Later Amish buildings consisted of concrete blocks.) ${ }^{79}$

The second priority was to establish an economic livelihood. One of the original cries for this settlement was the need in Honduras for small-scale agricultural development - skills Amish could offer - so naturally most went into farming, including five of the six Stolls, ${ }^{80}$ Monroe Hochstetler, two Nappanee families, and late-comers David Peachey and John Martin. Agricultural outputs included livestock for meat, dairy for milk and cheese, produce, and potatoes. ${ }^{81}$ The Amish grew their crops in North American patterns, which the locals observed with curiosity. ${ }^{82}$ And with a warm climate year-long, the only thing keeping the Amish from growing two crops a year was the arid dry season, a hurdle they cleared by connecting a canal and irrigation system to the local creek. ${ }^{83}$

To replicate Amish-style farming required horses. While Hondurans used oxen for field work and small Spanish horses for personal transportation, the Amish rejected both: oxen were just too unfamiliar (if not also a bit brusque) and Spanish horses were too weak for demanding field work. Thus, the Amish arranged to import two medium-sized stallions and ten maresBelgians and mixed breeds - with the idea of breeding them. During the summer of 1969, the horses were hauled to Miami, flown to Tegucigalpa, and trucked back to Guaimaca. The horses remained with the Amish farmers for years, although some adjusted poorly to the hot Honduran climate $^{84}$ and succumbed to tropical disease, necessitating vaccinations. ${ }^{85}$ Through the years,

\footnotetext{
${ }^{75}$ Eicher, Childhood, 34,36; Hochstetler, Life and Times, 59,100,92,230,385.

${ }^{76}$ Hochstetler Life and Times, 72.

77 Ibid., 18.

${ }^{78}$ Stoll, Joseph, letter in The Budget, reprinted in ibid., 19.

${ }^{79}$ Eicher, Childhood, 34.

${ }^{80}$ Stoll, Sunshine, 283-86.

${ }^{81}$ Hochstetler, Life and Times, 296-97; Stoll, Sunshine, 283.

${ }^{82}$ Eicher, Childhood, 50.

${ }^{83}$ Ibid., 55.

${ }^{84}$ Ibid., 30; Hochstetler, Life and Times, 36-37; Stoll, Sunshine, 14-15.

${ }^{85}$ Eicher, Childhood, 42-43; Hochstetler, Life and Times, 48. Joseph Stoll counters Eicher's assessment of the horses doing poorly, stating in a June 15, 2016 letter, that the horses did well for those wanting them to do well, and not well for those who wanted tractors. Horses crossbred with native mares "resulted in tough, plucky animals that in many ways were superior to the imported horses."
} 
Joseph Stoll (for one) came to prefer local horses, albeit still holding oxen at arm's length. ${ }^{86}$ Horses for farm work were so unfamiliar to Hondurans that custom agents at the border could not fathom that a piece of equipment being taken in was to be put on a horse since horses are for riding. ${ }^{87}$

The Amish took their goods to different market centers for sale. In Guaimaca, the immediate population center, the townsfolk - and foreigners stationed there - tasted their fair share of Amish produce, meat, eggs, and baked goods through the years. ${ }^{88}$ Several farmers sought larger markets. Twice a week, Abner endured the four-hour bus ride west to the capital to

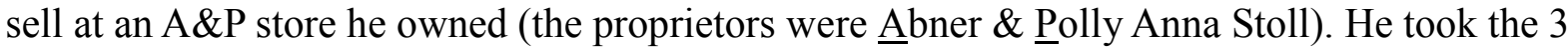
a.m. bus, the best one for an enterprising farmer: he could open soon after sunrise and be on his way home that afternoon. The store had overnight accommodations just in case. ${ }^{89}$ Taking the bus in the opposite direction, Leroy Hochstetler sold eggs in the Juticalpa, the regional capital. ${ }^{90}$

Along with these agricultural operations were several other businesses providing income, including David Peachey's feed mill and Richard Hochstetler's butcher shop. ${ }^{91}$ Sammy Eicher built up a machine shop, expanding from the one he operated before. In Aylmer, his shop, along with his aggressively expansive construction business, had been running up against the Aylmer Ordnung. Now he had more latitude to adopt once-forbidden technology. With both Amish and locals relying on his ability to repair parts, the shop stayed busy; oftentimes the missus delivered his supper to the shop. ${ }^{92}$ Only Peter Stoll's roadside store had no direct connection with agriculture, although it did provide the day-to-day social connection with locals he sought.

Adjustments to Honduras were many and minute: “...in a third-world country, [Amish] norms were completely upended, and they hardly knew where to begin setting them upright again." ${ }^{93}$ Homesickness — not just for friends but also the familiar-was endemic; one married daughter of Peter Stoll quickly wore a path between her parent's house and hers. ${ }^{94}$ Homes were Amish-style, all comparatively large by local standards, ${ }^{95}$ some including summer kitchens with walk-out basements. ${ }^{96}$ An Amish family moving to Paraguay stopped in at Guaimaca and was surprised upon seeing that the house they would lodge in "looked rather ordinary after all [...] almost like one [back home] in Iowa. [...] 'I didn't realize you had such nice houses here,' mama

\footnotetext{
${ }^{86}$ Eicher, Childhood, 201.

${ }^{87}$ Stoll, Sunshine, 279.

${ }^{88}$ Hochstetler, Life and Times, 133.

${ }^{89}$ Eicher, Childhood, 37; Hochstetler, Life and Times, 237,40; Stoll, Sunshine, 287-88.

${ }^{90}$ Hochstetler, Life and Times, 258.

${ }^{91}$ Ibid., 296-97; Stoll, Sunshine, 287.

${ }^{92}$ Eicher, Childhood, 23-26,36,55.

${ }^{93}$ Ibid., 93.

${ }^{94}$ Ibid., 53.

${ }^{95}$ Hochstetler, Life and Times, 397; Stoll, Sunshine, 50.

${ }^{96}$ Eicher, Childhood, 53,94.
} 
admitted to Emil's wife.' [...] 'Most of us do,' she told Mama."97 The similarities held, both outside and in. While the standard rural Honduran floor was dirt, Amish floors were waxed and varnished, ${ }^{98}$ no surprise given a general Amish preoccupation with orderliness expressed in housekeeping. One family, later moving into the hills, occupied a house with a dirt floor. Four times in Monroe Hochstetler's memoirs mention is made of the wife sweeping the dirt floor-all in vain-before finally pouring concrete. ${ }^{99}$ From the way they canned meat, cut wood, peeled fruit, or stored corn in a silo, ${ }^{100}$ the Amish defaulted back to many North American cultural habits as they adjusted to this dramatically new context.

One thing they could not transfer: their language of communication with outsiders. Locals knew Spanish and only Spanish, not English, and the Amish migrants came with basically no background in the language. Forever motivated to the next task, Peter Stoll established his roadside store basically so he could interact with locals and learn the language (which came quickly). ${ }^{101}$ Joseph Stoll also learned it quickly, in part thanks to a Spanish-fluent college student living with him whom the scholar Gertrude Huntington had referred. ${ }^{102}$ With this edge on Spanish, Joseph held language courses for the rest, teaching out of a textbook. The time people committed to studying — or the ability to pick it up — varied. ${ }^{103}$ In 1971, communication remained difficult for most. ${ }^{104}$ By the mid-1970s, Spanish fluency was much more commonplace, signaled by increasing acceptance of Spanish in church services. ${ }^{105}$ Some nevertheless struggled along. John Martin, ordained in 1976, found it difficult to preach in Spanish. ${ }^{106}$ Even the most fluent had not mastered the many nuances of the language. Case in point, while the colony had wanted to translate religious books from English to Spanish — among them Daniel Kauffman's 1,000 Questions and Answers - they found it difficult to express some ideas in Spanish or make applicable to the Latin culture. ${ }^{107}$

Although far from home, the Honduran Amish hardly felt isolated and cut off from other Anabaptist people. The Guaimaca Amish entertained many North American visitors, including Amish-Mennonites, conservative Mennonites, and mainstream Mennonites. Several times, whole busloads of Goshen College students showed up at the colony. This was in addition to any other curious non-Anabaptists who happened to pass by, from professors and medical doctors to backpackers and drifters, as well as two young Seventh Day Adventist young men from

\footnotetext{
${ }^{97}$ Rachel Hochstedler and Susan Wheary, Treasured Memories: An Iowa Family in the Chaco (Wyandotte, OK: Rachel Hochstedler, 2005), 23-24.

98 Stoll, Sunshine, 256.

${ }^{99}$ Hochstetler, Life and Times, 195,205-07,15.

${ }^{100}$ Ibid., 109,265; Stoll, Sunshine, 143.

${ }^{101}$ Hochstetler, Life and Times, 104,44.

102 Stoll, Sunshine, 108.

${ }^{103}$ Hochstetler, Life and Times, 40,120,397.

${ }^{104}$ Stoll, Sunshine, 136.

${ }^{105}$ Eicher, Childhood, 81-84; Hochstetler, Life and Times, 302; Stoll, Sunshine, 368-69.

${ }^{106}$ Eicher, Childhood, 234-35.

107 Stoll, Sunshine, 136,327.
} 
California who requested an Amish-style haircut. ${ }^{108}$ And of course, many Old and New Order Amish also visited the settlement. Furthermore, ties with Beachy Amish-Mennonites in neighboring countries grew. All three autobiographies make many passing mentions of visits to and visits from Beachy Amish-Mennonites in El Salvador, Costa Rica, and Belize. Richard Hochstetler, before settling into Guaimaca, had spent several months with the Costa Rican Beachys in language instruction, cementing ties to the Beachys there.

All-in-all, the Amish in Honduras did relatively well establishing themselves on Latin American soil. By the end of 1971, 12 families had settled in Honduras, nearly all of the couples in their upper 20 s to lower 40 s and with large broods. Three more families would move into Honduras by 1974, and with the addition of two married couples, the Amish population reached 17 families and three or four single girls associated with the children's home. ${ }^{109}$

\section{Fulfilling Their Mission}

While the focus of most new Amish settlements is on re-establishing patterns of religious community in a new context, the Guaimaca Amish had the added vision of being of service to the local people. In choosing Honduras (and rejecting North America), Peter Stoll not only selected a geographic context ideal for the recreation of an Amish community but also a cultural context that could stand to benefit from religiously, socially, and economically distinctive Amish offerings. The Amish efforts fall into three categories: childhood socialization, material aid and economic development, and religious outreach.

\section{Childhood Socialization}

First, the Amish attempted to apply their cultural and religious strengths of family stability and child socialization. ${ }^{110}$ While the Amish perceived the Hondurans as having a strong sense of community, the instability of household and family life was conspicuous: marriages solemnized by eloping, infidelity and adultery, persistent poverty, and parental inattention to child-rearing, this all amidst a high fertility rate. "Children are so plentiful here," remarked Monroe Hochstetler, observing how they lingered around his home at supper time, "that their parents probably never missed them."111

The most immediate remedy the Amish had for the surplus of uncared for children was to take them in as their own, giving them a stable family through grafting. Several families turned to adopting Honduran children, not the least of them being Peter Stoll, who adopted two children

\footnotetext{
${ }^{108}$ Ibid., 431.

${ }^{109}$ Ibid., 285-87, 457-59.

${ }^{110}$ Discussion of Amish family stability can be found in Ernest W. Burgess and Harvey J. Locke, The Family (New York: American Book Co., 1945), 78-92; Gertrude Enders Huntington, "The Amish Family," in Ethnic Families in America, ed. Charles H. Mindel, Robert W. Habenstein, and Roosevelt Jr. Wright (New York: Elsevier, 1981[1976]), 367-99.

${ }^{111}$ Hochstetler, Life and Times, 35.
} 
shortly after arriving. ${ }^{112} \mathrm{He}$ also helped families with children for the short term, as with a woman, boy, and baby found homeless and sick in Guaimaca, whom Peter put up in an empty chicken house until they were well enough to return to Guaimaca. ${ }^{113}$ Several others also adopted children. Danny Stoltzfus and his wife adopted a child soon upon arriving in Honduras. ${ }^{114}$ Richard Hochstetler adopted a one-month old boy. ${ }^{115}$ Eight adopted children were numbered among siblings John, Lizzie, and Ada Martin by the end of 1974, some adopted in Belize, others in Honduras, some before they were married, some after. Beyond the Guaimaca colony families, Amish in North America also took an interest in adopting Honduran babies, especially after a hurricane struck the country in 1974. ${ }^{116}$ The adopting out of Honduran babies to North America, begun while the settlement was still Amish, would continue after they left and through the 1980s among those remaining.

While families adopted Honduran children, the Amish also institutionalized adoption through the creation of the Colonia Sansón Children's Home. The goal of the home was to "duplicat[e] a normal family situation [...] That is God's order and plan-children are to grow up within a family, where they experience love and discipline and can form intimate parent-child relationships." "117 The vision for the home stretched back to Peter Stoll's work among Ojibwa in Ontario, although his vision of a home never materialized there. A more immediate inspiration for a children's home was the Youngberg orphanage. In the first years of the Guaimaca settlement, Ira Stoll and four single girls were back and forth between the two, until they constructed their own children's home in $1970 .{ }^{118}$ The two-story house was built near the pond and the future site of the church-school, at the center of the Finca Sansón colony. ${ }^{119}$ At first, the four single young women-sisters Lizzie and Erma Schmucker, Lydia Mae Hochstetler, and Martha Schlabach ${ }^{120}$ — all lived together in the home, taking in abandoned children, but because the Amish desired to avoid an institutionalized setting, they constructed four smaller homes for each of the mothers to individually raise their three to four adopted children. (At least one of the adopted girls was so well socialized into the Amish world that she learned Pennsylvania Dutch fluently enough to use it regularly later in her adulthood.) ${ }^{121}$ An administrator living in the main

\footnotetext{
112 Ibid., 84-85, 103-04.

113 Ibid., 41.

114 Stoll, Sunshine, 179,286-87.

115 Ibid., 336.

${ }^{116}$ Ibid., 340.

${ }^{117}$ Ibid., 102.

${ }^{118}$ The home was constructed from February to March 1970. Monroe Hochstetler's family moved into it temporarily upon arrival while they built their home. Once they moved to their new home in October, the Schmucker girls occupied the Children's Home, sharing it with their brother Vernon and his family while they built a home. Ibid., $58,62-63,73,85,89,96$.

${ }^{119}$ Ibid., 284.

${ }^{120}$ Martha Schlabach later became the secretary-treasurer; she also taught at the colony school (along with Sarah Stoll one year and John Martin the next) and was involved in other outreach work. Martha moved in with Lydia Mae and Ada Martin replaced Martha as a mother. Hochstetler, Life and Times, 180-81; Stoll, Sunshine, 97,222,87.

${ }^{121}$ Hochstetler, Life and Times, 395.
} 
home served as a "father" image. ${ }^{122}$ The role was first held by Ira Stoll, and then in April 1974, Danny (and Sadie) Stoltzfus moved in, taking on the administrator responsibilities. ${ }^{123}$

A less total option than adoption to socializing children was a Spanish school. The school was near the Children's Home and church-school building, but was separate from the school for Amish children. After a month of construction, the school opened in February 1973 under Mark Stoll's tutelage. The school accepted children from poor families who otherwise could not afford to attend school and focused on teaching children to read and write. Some had never attended school before. ${ }^{124}$ While these children did not board at the colony, they spent many hours among the Amish through the week, witnessing their ways. Several children would later join the church.

\section{Material Aid and Economic Development}

The second application of Amish cultural strengths to Honduran challenges was in the form of material aid and economic development. The Amish have a propensity to develop strong, successful livelihoods, from farming to businesses. ${ }^{125}$ Given the Honduran conditions of widespread economic depravity, low productivity and subsistence nature of agriculture, and limited tools and methods to establish farms and businesses, the Amish applied their knack for enterprising to assist.

Poverty was omnipresent and conspicuous to the Amish. In a March 1971 diary entry, Joseph Stoll reflected on a restlessness and discouragement he felt, wondering if its source was in the relative wealth he enjoyed while poverty abounded around him. The problems such a gap brought, he wrote, included the temptation to look down on Hondurans and the arousal of envy and theft. Were they not living up to their commitment to live close to the level of the local people, he asked, as he grappled with the colony-wide adoption of kerosene refrigerators. Ira Stoll later testified in church that God may have allowed a major robbery because the Amish were living in luxury while locals were suffering a widespread crop failure. The testimony inspired Joseph to rewrite God's message to the seven churches in Revelation for the Guaimaca Amish church: they enjoyed corn flakes, Jell-O, and soda crackers while closing their eyes to and being harsh with the Hondurans, pursued a comfortable living while neglecting to spread the gospel message. ${ }^{126}$

One response was to employ local laborers. Some, like Cristobal Irias, were invited to live among the Amish, both working for the Amish and operating personal income-generating projects on the side, like a chicken house. Cristobal was also one of the first to join the church

\footnotetext{
${ }^{122}$ Stoll, Sunshine, 102-03,287.

${ }^{123}$ Ibid., 286.

${ }^{124}$ Ibid., 215,37,84,417.

${ }^{125}$ Period-specific discussion of Amish values and discipline in business and agriculture can be found in Victor Stoltzfus, “Amish Agriculture: Adaptive Strategies for Economic Survival of Community Life," Rural Sociology 38, no. 2 (1973); William H. Martineau and Rhonda Sayres MacQueen, "Occupational Differentiation among the Old Order Amish,” ibid.42, no. 3 (1977).

${ }^{126}$ Stoll, Sunshine, 116-18,214-16.
} 
and marry into the Amish. For his worker Calixto Irias, Monroe Hochstetler built a house, stating, "We were hoping we could help them in more ways than just finances. We wanted to sow seeds for the Master." ${ }^{127}$ Monroe also makes note of his chauffer, Julio, who had a truck. ${ }^{128}$ Sammy Eicher hired Fausto and his two-man crew to dig into a shale hill with non-motorized tools so that his wife could have a walk-out basement. "Fausto saw more than just a basement needing to be dug... [Here was] someone who wouldn't disappear on him next week. A person who wouldn't be out of money when payday arrived." The job took over four months. Fausto's reliability and determination won Sammy's confidence, and he continued to hire him for oddjobs on a weekly basis. ${ }^{129}$ Joseph Stoll had three laborers at one point, including Ramiro, who was "one of the hardest-working men we have yet seen. When he swings a hoe or a machete, his shirt is wringing wet." 130

To the Amish, employment was contingent on their employees' honesty and diligence, traits they hoped to encourage more broadly among Honduras's workforce. The Amish did face moments when they suspected that their employees were being dishonest; sometimes the suspicions were justified, leading to dismissals, sometimes the Amish were mistaken, leading to regrets. $^{131}$

While the Amish were partial to able workers, they also hired those suffering misfortunes and disabilities. Emil Helmuth hired a poor widower with children and David Peachey hired a man going blind and missing an arm. ${ }^{132}$ This mirrors their culture's emphasis on allowing everyone to contribute no matter the skill level, as with elderly or special needs people. ${ }^{133}$

One of the rationales for settlement in Honduras over Prince Edward Island was the need for agricultural development in Central America, which did not share the cornucopian bounty of North American fields. The ways Amish promoted agriculture in Honduras - in addition to becoming farmers themselves-were many. Some help focused on livestock. The Heifer Project provided adult animals to the poor with the agreement that the first born is returned to the project; North American sponsors donated the animals. ${ }^{134}$ In addition to familiar livestock, Ira Stoll, convinced of their merit, promoted goats in the area for milk and meat, although the Honduran's attraction to these bearded, bleating creatures was about as strong as the Amish toward the Honduran's beast of burden, the ox. ${ }^{135}$

Other aid pertained to providing supplies, land, and advice. The Helping Hand program

\footnotetext{
${ }^{127}$ Hochstetler, Life and Times, 116-17.

${ }^{128}$ Ibid., 137.

${ }^{129}$ Eicher, Childhood, 94.

${ }^{130}$ Stoll, Sunshine, 319.

${ }^{131}$ Ibid., 209.

${ }^{132}$ Hochstetler, Life and Times, 309,46.

${ }^{133}$ Eileen Andreoli and Judith Miller, "Aging in an Amish Community," Nurse Connections 11, no. 3 (1998): 5-11; Ruth Cavan, "Roles of the Old in Personal and Impersonal Societies," Family Coordinator 27, no. 4 (1978): 315-19.

${ }^{134}$ Stoll, Sunshine, 297.

${ }^{135}$ Eicher, Childhood, 168; Stoll, Sunshine, 297-98.
} 
donated start-up supplies (and Amish supervision) for young farmers; the first round of assistance consisted of nearly 100 bags of seed potatoes distributed to 20 farmers. ${ }^{136}$ Helping Hand also loaned money to farmers so they could buy land. They were furthermore included on a farm implement borrowing schedule (this, too, included oversight and advice the first several years). ${ }^{137}$ "These Honduran farmers are quite happy with the profit they are making..." wrote Joseph Stoll. ${ }^{138}$

The colony also promoted agricultural innovation and implement diffusion. Locals from around Guaimaca often came out to Amish farms to watch their field work, which was carried out with work horses. Through the weeks and months, the Amish dropped hints that, indeed, horses, even smaller ones, can be an asset to field work.

The Amish also caught the eye of agricultural development agents when they assisted in the clean-up after Hurricane Fifi hit the north coast in 1974. When approached by agents, Joseph Stoll consented to try out, comment on, and demonstrate for officials a new walking plow designed by an international development agency. ${ }^{139}$ And though he was offered a large salary to go around the country teaching Hondurans to use this plow, Joseph declined, focusing instead on local, internal efforts. For one, Joseph was active in other tool diffusion efforts, importing used horse-scale implements from North America. The culmination of this effort was when the community received three boxes of tools weighing 12.5 tons, implements collected from Amish and Amish-Mennonite churches in Holmes County, OH, Kentucky, Tennessee, and Georgia. ${ }^{140}$ Yet by 1978, with the departure of the Stolls, donated tools were not being distributed. The Stolls were the drivers of the Helping Hand program, and the families remaining in Honduras adopted tractors for personal field work. They felt that they should leave well enough alone with the Honduran farmers and their oxen. ${ }^{141}$

The most direct form of assistance was the Poor Ladies Program. David Peachey solicited sponsorships through The Budget. "There aren't that many direct Amish charities [...] And this one sounded good" wrote Jerry Eicher, "- - helping downtrodden women of the third world better their lives, all on a pittance of ten dollars a week. A sound investment indeed [...] And it was run by honest Amish men who kept none of the proceeds..." Accordingly, individual sponsorships flowed in. ${ }^{142}$ Three committee men interviewed candidates (and their neighbors) to make sure they were truly in need and that these women had no men providing support. The ladies accepted for the program would come by the colony store to receive weekly provisions. In exchange, they

\footnotetext{
${ }^{136}$ Stoll Sunshine, 373.

${ }^{137}$ Ibid., 366,422.

${ }^{138}$ Ibid., 385.

${ }^{139}$ Ibid., 321-22; Eicher, Childhood, 201-02.

${ }^{140}$ Hochstetler, Life and Times, 334-35; Stoll, Sunshine, 414.

${ }^{141}$ David Peachey, "Guaimaca F.M., Honduras Ca," The Budget, June 21, 1978, 7.

${ }^{142}$ Hochstetler, Life and Times, 272-73.
} 
would do a few small tasks around the colony once a week. ${ }^{143}$

From time-to-time, reports flowed back to the committee of a woman whose need was not so great or who had a new man in her life, so the committee would make a surprise weekend visit to investigate, but no test proved perfect. Some women learned to keep the house male-free on weekends; others were mistakenly cut off due to rumors. ${ }^{144}$ "This program needs constant supervision," wrote Joseph Stoll, who went on to note that in a 1974 purge, the number of sponsored women went from 22 to $15 .{ }^{145}$ Despite frustrations, they took hope that the program at least helped some truly needy cases. ${ }^{146}$

It would be misrepresentative to portray the Hondurans as solely receivers and not also givers in their own right, despite economic limitations. Often, generosity came in the form of food, whether in bringing food for the meal after the church service, hosting the Amish for a meal, or giving them gifts of food, like a chicken. ${ }^{147}$ Even when the committee men made a routine visit to a lady on the Poor Ladies program, she very well may have invited them to have a seat for a visit and make some coffee. ${ }^{148}$

\section{Religious Outreach}

What set the Amish efforts apart from the many secular development and aid programs surrounding them in the 1970s was the Amish tendency to spiritualize the plight of Hondurans. The link between religious and economic deprivation is never stated clearly, but in the minds of the Amish settlers the two were closely related. "[...] the root of the problem is very much spiritual in nature, and the only complete solution is a living, true faith in Christ," Joseph Stoll stated. Is that it, though? He continues. "But even then there would continue to be hardships. It is [neither] fair nor honest to think that all that separates these people from prosperity is a little hard work and right living." "149 Even if the relationship between the lived experiences and the religious condition of the Hondurans is not hammered out into a fine theology, the Amish did something characteristically Old Order - connect the two, not in a hackneyed "material needs" and "spiritual needs" dichotomy, the mission trying to meet both, but through interweaving the two, much as they viewed their own lived realities in North America. They responded to perceived shortcomings of locals' lived conditions by demonstrating elements of an alternative, by modeling religious values.

One opportunity was in their response to crime. Because of their wealth and rural location, the Amish were vulnerable to perennial thefts: pick pocketing, nighttime livestock

\footnotetext{
${ }^{143}$ Ibid., 301,93; Stoll, Sunshine, 297.

${ }^{144}$ Hochstetler, Life and Times, 301,07; Eicher, Childhood, 112-13; Stoll, Sunshine, 365-66.

${ }^{145}$ Stoll Sunshine, 297.

${ }^{146}$ Eicher, Childhood, 113; Stoll, Sunshine, 387.

${ }^{147}$ Hochstetler, Life and Times, 210,15,22.

${ }^{148}$ Ibid., 121.

${ }^{149}$ Stoll, Sunshine, 366.
} 
rustling, shoplifting, clever schemes, break-ins, even face-to-face armed robbery. The Amish had to show, again and again, that they would not retaliate, not personally, not with the police, ${ }^{150}$ not by - as was common among locals - spreading rumors of revenge in town. Working, and not stealing, was the way of life that honored God, they told the red-handed. ${ }^{151}$ Sammy Eicher hung signs around his shop stating stealing is wrong; so the illiterate would not be excluded, the signs included eyes. ${ }^{152}$ Amish ways did win some admiration. Peter Stoll was a notable example. His horse was stolen one night, but surprisingly returned — with saddle marks - the following day; possibly the thief or his friends found out whose horse that was. ${ }^{153}$ At Peter's funeral, many locals came, filling the church house. ${ }^{154}$

With any cankerous dilemma, objectives become fuzzy, and with ongoing theft, the line between exhibiting religious values in the face of adversity and protecting one's interests was often blurred. If the Amish remained fully faithful to nonresistance through all the trials, then their responses can only be classed as theft deterrence. They specialized in addressing petty and non-confrontational thefts, answering the thieves' cleverness with their own, tit-for-tat. To deter nighttime theft, they first organized a nighttime posse (until they got shot at), then added metal bars to windows and doors, then installed ship horns on homes, then allowed (or rather, neglected to forbid) their workers to fire a gun into the air when trouble seemed amidst. ${ }^{155}$ Sammy Eicher strung a wire from his shop to his house that activated the generator, throwing lights on around the shop and across the lawn. "The situation wasn't something that couldn't be solved or controlled, the men reasoned," Jerry Eicher recounted. ${ }^{156}$ Sometimes the sheer cleverness of thieves intrigued the Amish like a new Ordnung work-around, as with the boy who purchased a few low priced goods with a large counterfeit bill and pocketed the change, a story told by all three authors. ${ }^{157}$

While making proselytes was not the explicit goal of the Amish, neither did they turn people away. Many more locals took interest in joining the Amish than ever seekers did the North Americans, which the Amish sometimes wrote off as ulterior motives: a free meal, a possible job, maybe even an Amish wife. ${ }^{158}$ Some continued attending after initial interest died down. A few did eventually join, three in all by $1975,{ }^{159}$ although the number may have been

\footnotetext{
${ }^{150}$ They did call the police out once, with regret, as the police created more of a hassle than they helped. Eicher, Childhood, 128-37.

${ }^{151}$ Ibid., 81-83; Hochstetler, Life and Times, 371.

${ }^{152}$ Eicher, Childhood, 56-57.

153 Ibid., 66.

154 Ibid., 69.

155 Ibid., 43,138-41; Hochstetler, Life and Times, 319.

${ }^{156}$ Eicher, Childhood, 43,138-41; Hochstetler, Life and Times, 319.

${ }^{157}$ Eicher, Childhood, 90-91; Hochstetler, Life and Times, 145-46; Stoll, Sunshine, 296-97.

${ }^{158}$ Eicher, Childhood, 50-51,63,104,07,17,20.

159 Stoll, Sunshine, 370.
} 
around 10 or more by $1978 .^{160}$ The number of regular attendees was probably yet more.

A subtle difference exists between modeling Christian behavior and articulating Christian beliefs. Heavy articulation tends toward the abstract, something many traditional societies the globe over dabble little with. Small signs exist that articulation of beliefs became more of a priority in the Amish settlement's later years. Monroe Hochstetler interviewed a man who, after working for Emil Helmuth, decided he wanted to join Emil's church. This was the sort of pattern Old Order-style mission would accept: a worker / friend in time admires the ways of the people he is among and wants to become part of it. A conceptual / theological form of mission like evangelicalism, however, stresses ideas and language that must be affirmed, a conflict brought out in this exchange between Monroe and Emil's worker:

'Do you believe in Christ?' / 'Yes.' / 'Do you believe in Him as your Savior?' / 'Yes.' / 'Do you want to join our church?' / 'Yes.' / 'Do you believe in the Virgin Mary?' / 'Yes.' / 'Do you believe in the saints?' / 'Yes.' / 'But you can't believe in Christ and also in the Virgin Mary and the saints, as that is idolatry. You must believe in Christ alone as your Savior.' / 'Well, okay, that is the way I believe now.' 161

Monroe likely thought he needed to have patience with this man, although this man may have harbored the same sentiment toward Monroe. Not long after, Monroe preached at the San Marcos church planting about "the new birth," but the locals said that they found it difficult to understand. This was the outreach that started largely out of a Bible study, which gained momentum as kin and friends wanted to join. Soon after this sermon, Monroe records that it was "thrilling to have people come to the church [...] and have faith in Jesus Christ as their personal Savior and Lord of their lives," certainly a jargon-based depiction more characteristic of evangelical lingo than probably any concept drawing the, nevertheless earnest, converts (short of repeating the words back verbatim). ${ }^{162}$ Monroe later praises one young convert for being articulate and debating fine theological points with a Catholic priest. ${ }^{163}$

The San Marcos church had many more converts than Guaimaca but consisted of only two Amish families. ${ }^{164}$ Its relative success may have had an impact on those pushing against the Ordnung. While Joseph Stoll was concerned about whether the Amish church was stable enough to provide for converts in a new church, ${ }^{165}$ the progressive families likely saw the precedent of re-establishing Amish community and Ordnung every time a new settlement starts as only getting in the way of a greater need: converting souls. The difference of winning (evangelical) and integrating / discipling (Old Order) converts is clear. In a visit to Guaimaca ten years after it

\footnotetext{
${ }^{160}$ Several additional baptisms are noted from 1976-78, and there may have been more. Hochstetler, Life and Times, 328-29,63; Stoll, Sunshine, 402-03.

${ }^{161}$ Hochstetler, Life and Times, 310.

${ }^{162}$ Ibid., 312, 14.

${ }^{163}$ Ibid., 354.

${ }^{164}$ Ibid., 360.

${ }^{165}$ Stoll, Sunshine, 378.
} 
broke from Amish affiliation, Joseph hints at how, among those who stayed, the focus shifted toward the abstract and evangelical mission-type phrases (with emphasis on these phrases added in italics, contrasted to the Amish "city on a hill," underlined):

In their optimism, they may still paint a rosy picture of souls won and of light breaking through and of freedom from bondage. We must leave that for God to judge, but tonight I can only remember the temple that used to be. ${ }^{166}$

\section{Church Unrest and Disaffiliation with the Amish}

The Old Order-minded modes of mission that Peter Stoll offered to local Guaimacans demanded a strong sense of self-consciousness: "Who are we and who are they whom we wish to help, and what is the bridge between?" Around these questions, Peter Stoll not only had a formula for the way the Amish community could be effective among the local Hondurans but also the justification for why the Amish community should remain what they were, a defense of their Ordnung. However, around a decade after establishment, the Ordnung had unraveled at least insomuch as it was an Amish Ordnung, and those wishing to remain Amish left the community. The loss of Amishness was also accompanied by a loss of distinctively Amish mission programs, which were gradually replaced by evangelical-style mission emphases and strategies.

How life goes in the first years of an Amish settlement is a strong indicator as to whether it will persist or not. Most Amish settlements that fail do so not long after beginning. Within the very year that the last of the initial families arrived, the clouds of unrest started spritzing on Guaimaca. Stephen Stoll, a conservative deacon from Aylmer, found himself at odds with progressive trends, trends accepted not just by the more progressive-minded Nappanee migrants, but some Aylmer settlers as well. The new settlement had made several departures from positions Amish widely held at the time. For one, soon upon arrival the settlers adopted kerosene refrigerators, a convenience still restricted in the origin communities. ${ }^{167}$ Other technology restricted in North America was winked at in Honduras, including the highly mechanized welding and repair shop of Sammy Eicher. ${ }^{168}$ Additionally, given the walking distance among church family homes and the ease of public transportation, the horse and buggy - a mode of transportation highly symbolic of modern Amishness — was rarely used. ${ }^{169}$

Beyond technology, there were immediate changes in religious rituals. In the autumn of 1970, the community was constructing a modest-sized community center-similar to those of the Amish-Mennonites - housing a sanctuary and two school classrooms under one roof. The first

\footnotetext{
${ }^{166}$ Ibid., 454.

${ }^{167}$ Dachang Cong, "Amish Factionalism and Technological Change: A Case Study of Kerosene Refrigerators and Conservatism," Ethnology 31, no. 3 (1992).

${ }^{168}$ Eicher, Childhood, 219; Stoll, Sunshine, 371.

${ }^{169}$ Eicher, Childhood, 128.
} 
service was in December $1970 .^{170}$

Two months before the completion of the church house, Stephen Stoll was critically injured. In what he thought were his final moments, he let out some concern about church drift. ${ }^{171}$ Stephen made a miraculous recovery over the next months, but his comments indicated some growing concerns. An ideological fracture was becoming visible, and it was visible before all of the initial families even arrived. Only by the next month would the Nappanee ministers Vernon Schmucker and Richard Hochstetler actually arrive to stay in Guaimaca. What was Stephen's concern? Part of it was not so much a growing Aylmer / Nappanee division-which is how the conflict later unfolded - as to some initial differences within the Aylmer group. The other part was directly concerned with Richard Hochstetler. Being among the Beachys in Costa Rica for language lessons prior to moving into Guiamaca, Richard fraternized freely, to the point where Peter asked him to not accept preaching requests. ${ }^{172}$ Richard did, after all, plan to join the Amish settlement. For an Amish minister to preach and fellowship with an automobile-accepting Beachy church confronts a distinctive boundary of Amishness. In the coming years, Richard, perhaps more than the other Nappanee families, would come to be the main momentum behind of the progressives.

With the arrival of Richard Hochstetler and Vernon Schmucker in November 1970, the church attempted to forge unity through a new Ordnung during the winter and spring of 1971, and, somehow, they managed to reconcile two different settlement backgrounds into an Ordnung for a new settlement. One of the more critical points they discussed was whether the Ordnung should apply equally to the Amish and local converts. Already, the question of the Ordnung's utility to the Honduran setting was raised. Though they evidently required their Ordnung for locals, skepticism of such a decision persisted through the decade.

But for the moment, with an Ordnung in place, the church could proceed with communion. For a few weeks in May, Bishop Wally Byler was delayed from coming until "some difficulties that have come up" between the two Nappanee ministers-Vernon Schmucker and Richard Hochstetler - and their former church could be resolved. Evidently, there was either a break-through or an impasse, as the next month Wally arrived, performed a baptism, held communion, and officiated over a minister ordination; Monroe Hochstetler was chosen, the Aylmer migrant originally from Nappanee. ${ }^{173}$

Having four ordained men - three ministers and a deacon — in a new Amish settlement would normally point to community success. However, that August, the ministers admonished

\footnotetext{
${ }^{170}$ While Amish settlements with roots tracing back to Somerset County, PA, often have meetinghouses as a fluke of history (see Alvin J. Beachy, "The Amish Settlement in Somerset County, Pennsylvania," Mennonite Quarterly Review 28, no. 4 (1954): 278), the Honduras settlers built one without a precedent from any of their origin communities

${ }^{171}$ Eicher, Childhood, 46-48; Stoll, Sunshine, 89-94.

${ }^{172}$ Letter from Joseph Stoll to authors, June 15, 2016.

${ }^{173}$ Stoll, Sunshine, 129-30; Hochstetler, Life and Times, 86-87.
} 
the congregation to "live up to your confession," that is, the Ordnung adopted just several months prior. ${ }^{174}$ In October, Joseph Stoll reflected in his diary that church stability still had not been achieved. ${ }^{175}$ Evidently, the church had not reached peace upon its founding, a critical malfunction at the beginning that would continue to plague the settlement.

If there was hope for stability, it was to be found in a mediator. The two most promising bridges - Peter Stoll and Monroe Hochstetler — were ultimately ill-fated. First, in October of 1971, Peter Stoll, who was a go-between more than anyone else, who had founded the community, who had inspired North American Amishmen to relocate far from the familiar, the "center pin that held the life of the community together [...] the one we could least afford to lose" was lost. ${ }^{176}$ He suffered from a sudden heart attack mid-day on the $7^{\text {th }}$, and by the day's close he had passed on. While the community was aware that he was having heart trouble, the sudden death still caught them off guard. ${ }^{177}$ Many settlers would reflect back on this event as the most critical juncture for the path the settlement took. "Even with his passion for mission outreach and his hand in founding an Amish settlement on foreign soil," wrote Jerry Eicher, "he believed both to lie well within the will and protection of God. And if he had lived he might have kept things from running over the edge." 178 Peter had charisma, and without that charisma, what other mechanism could be found to move a troubled young Amish community across the hurdle of its first years?

A second hope was in a bishop ordination. Minister Monroe Hochstetler was a strong candidate. He had lived a short time in Aylmer before moving to Honduras with the Stolls, but was originally from Nappanee and considered the migrants from there his kin. In February 1972, Wally Byler made his final visit to Honduras, conducting baptisms and a bishop ordination. He had wanted to ordain a bishop earlier, but some members, especially the Aylmer folks, desired a third minister before the bishophoric was opened. ${ }^{179}$ With Monroe ordained minister in 1971, Wally commenced with the bishop ordination. All three ministers were in the lot when Monroe was chosen.

However, Monroe did not prove to be that perfect replacement for Peter but rather a prolonger of an inevitable division. On one hand, he may have been unaware of, or unwilling to acknowledge, the magnitude of church tensions. For instance, on one occasion, the school children sang "They Locked God Outside," which troubled Joseph Stoll for its nonchalant, superficial lyrics. However, Monroe stated he had thought nothing of it, shrugging off the concern. ${ }^{180}$ Tellingly, Monroe's Honduras autobiography does not reveal any church troubles until page 380 out of 406, while Joseph Stoll's and Jerry Eicher's accounts draw attention to

\footnotetext{
${ }^{174}$ Stoll, Sunshine.

${ }^{175}$ Ibid., 43.

${ }^{176}$ Hochstetler, Life and Times, 101-04; Stoll, Sunshine; Eicher, Childhood, 68-69.

${ }_{177}$ Stoll, Sunshine, 150-51; Hochstetler, Life and Times, 101-04.

${ }^{178}$ Eicher, Childhood, 73.

${ }^{179}$ It is not customary for a deacon, like Stephen Stoll, to be in the lot for bishop.

${ }^{180}$ Stoll, Sunshine, 381.
} 
church difficulties throughout.

On the other hand, Monroe may have been as devotedly moderate as the poles were grounded in Amishness or evangelicalism. A moderate maintains his leadership position by keeping the opposite poles in some tension so they both must look to the middle for assistance. Jerry Eicher refers to Monroe as doing a "neutral dance" when conflict arose. He had "a heart of gold [but he] didn't have a clue regarding the politics of the leadership position [and] the maze of Amish church relationships [...] He would lose his church eventually."181

Changes were initially slow, yet present, under the new bishop. Through 1972 and 1973, several practices shifted without much fuss. One noteworthy incident of Honduran culture throwing Amish practice into question was with the black felt hats. These hats were used primarily for dress-up wear. To Hondurans, black felt hats were a sign of wealth and status; the bigger, the better. David Peachey alone was robbed of four hats. Gradually, the Amish adopted straw hats for black hat occasions. ${ }^{182}$ After all, how could they require of converts a piece of clothing that to the Amish spoke of humility but to the Hondurans spoke of prestige?

The transition away from black felt hats could have remained an isolated issue, but it was used as case-in-point evidence that other dress requirements embodied similar contradictions in Honduras, even if a given contradiction was less evident. "We did not think of all those things when we were thinking of coming down," reflected Vernon and Katie Schmucker years later. "If people had a desire for the Word of God and change their lives, why make them get so detailed, so much detail?" "183 Other clothing practices were either changed or came under ongoing stress. For one, full button-down shirts came to replace the three-button style shirts still used in Aylmer at the time. ${ }^{184}$ Further, arguments were pressed that it was impractical for converts to wear suspenders, home-sewn clothes, ${ }^{185}$ and aprons. ${ }^{186}$ This polarization over clothing among adults played out even among the children. When the boys went for a hike, the Schmucker and Hochstetler boys shed their suspenders and parted their hair crookedly. The Stoll boys disregarded the prevailing mood and later reported the breach to their parents. ${ }^{187}$

To the conservatives, there seemed no end to Amish practices that could come under scrutiny. Over the winter of 1972-73, Deacon Stephen Stoll began to contemplate and share quietly his thoughts of returning to Aylmer because of the liberal trends. This was discouraging to other conservatives, who saw him as their sole representative on the ministerial bench. Over the summer of 1973, his family took an extended trip to North America to visit. Other families were also making visits back to North America by 1973, so nothing may have seemed out of the

\footnotetext{
${ }^{181}$ Eicher, Childhood, 64-65.

${ }^{182}$ Ibid., 118-20; Stoll, Sunshine, 203.

${ }^{183}$ Interview with Vernon and Katie Schmucker.

${ }^{184}$ Eicher, Childhood, 157.

${ }^{185}$ Ibid., 120.

${ }^{186}$ Interview with Vernon and Katie Schmucker.

${ }^{187}$ Eicher, Childhood, 162,64.
} 
ordinary, but Stephen went to consider the logistics of moving back. After returning, he preached a strong sermon in church about straying from the Ordnung: this experiment, of adjusting Amishness to a mission-vision for Honduras, was not working, as it weakened the Ordnung. After sharing, he stated his intention of leaving. In November 1973, the family held a farm auction and in February held a second, final auction for equipment and household goods. The family then packed their remaining possessions onto "the Bluebird"- - a conservative Mennoniteowned bus that chartered trips between North and Central America-and headed for Aylmer. ${ }^{188}$

The Amish families of Guaimaca received variously the announcement of Stephen's pending departure. Monroe responded with detachment:

Stephen shared his concerns about the church here in Guaimaca, and as part of the ministry, he would rather move than cause any strife. We appreciated him for that. It saddened us to see them leave, but we wish them God's blessings wherever they may be. $^{189}$

To conservatives, Stephen's departure was an omen that they too will someday need to consider alternatives. As Jerry Eicher put it, Stephen's departure was like "a mine canary dying" 190 And yet, no others were serious enough to move out. ${ }^{191}$ After all, only with much effort had they moved and adjusted to Honduras; it would take some effort to pry them from their new homes.

In spite of their differences, they were developing sentimental bonds through living and working in close proximity, not unlike colony Mennonites and Hutterites. Furthermore, the colony prospered. Despite initial setbacks, the functions of Amish community were buzzing along. All families met with success in farming and other enterprises, and three weddings plus multiple baptisms had taken place. Additional people moved in, including Alvin Miller's family of five from Nappanee and, from Belize, three siblings, John, Ada, and Lizzie Martin. ${ }^{192}$ Marriages were occurring and new households being established. The young couple Ira and Lizzie (Martin) Stoll moved into Stephen's vacated house.

What is more, 1974 afforded the colony two outreach opportunities, possibly cementing a sense of solidarity around a common, outward-looking goal. The first was a church mission in the mountains. While some locals had attended the Guaimaca church, the Amish were in general suspicious of seeker motivation. In the mountains south of Guaimaca, interest arose in Bible classes after Richard and Monroe visited the area several times. Classes began in December 1973. ${ }^{193}$ The people in the mountain village of San Marcos impressed the Amish as harder working and more forthright than the town people around Guaimaca. Additionally, the Amish

\footnotetext{
${ }^{188}$ Ibid., 116-17; Stoll, Sunshine, 232,34-35,69,77,89-90.

${ }^{189}$ Hochstetler, Life and Times, 189.

${ }^{190}$ Eicher, Childhood, 173.

${ }^{191}$ Stoll, Sunshine, 269.

${ }^{192}$ Ibid., 257-58.

${ }^{193}$ Ibid., 280.
} 
could better guide a cadre of seekers from a distance than they could integrate seekers into their day-to-day lives in Guaimaca, where socioeconomic class and cultural differences were otherwise conspicuously fixed in a way contradictive of the equalizing mechanisms of Amish religiosity. By spring 1974, enough people in San Marcos expressed interest in a church that the Amish built a residence to house a minister and hold services. Monroe's family first moved there on June 20, with Richard making extended visits through the summer. Although the most interested seeker experienced a fatal accident that summer, the church was able to continue with others. $^{194}$

The second outreach was a humanitarian response to Hurricane Fifi's ravaging of the north coast in September 1974. After scouting out the damage, the Amish sent a groupincluding both ethnic Amish and converts - to help with cleanup. Along with other humanitarian aid groups, the Amish stationed themselves in the region for several months, distributing food in the early days and then reconstructing homes. To sponsor the event, the Amish initially dipped into the Poor Ladies fund, until waves of donations swept ashore in response to a request for help printed in The Budget, enough to support a full-time crew. Richard Hochstetler, who had been involved in San Marcos, spent two months in the disaster area, from late November 1974 to late January $1975 .^{195}$

Yet in the midst of these efforts, the Amish slid ever deeper into an Ordnung impasse, which included new points of tension. With Stephen's exodus, more attention was given to discontinuing German. Stephen undoubtedly insisted on keeping German preaching and singing as normative, but no advocates remained on the ministers' bench after his departure. For the settlement's first years, a little Spanish was used on special occasions, as during weddings when many Hondurans were present and ministers thought slipping in some teaching on Christian home life was too good an opportunity to pass up. Beginning in 1974, about five years into learning the language, Spanish in church services expanded. Hymns were the first site of switching. Those who wanted more Spanish picked Spanish songs, while the German advocates returned suit; in the mix, incidentally enough, were selections of English songs, often selected by the children's home administrator, Danny Stoltzfus. ${ }^{196}$ The new outreach in San Marcos also opened up more opportunities to switch to Spanish, since interest arose out of Bible study.

Moves toward Spanish were gradual in 1974, but by May 1975, the transition was accelerating. Ministers starting preaching short Spanish sermons on days when a large number of Hondurans were present. ${ }^{197}$ During the summer of 1975, Monroe took the step to start preaching in Spanish regularly, with the other ministers soon following. ${ }^{198}$ This sudden shift raised spirited debates. The liberals argued that to juggle three languages_English, Spanish, and German —was

\footnotetext{
${ }^{194}$ Eicher, Childhood, 178-79; Hochstetler, Life and Times, 191-92,99-200,26; Stoll, Sunshine, 298-99.

${ }^{195}$ Eicher, Childhood, 198-200; Hochstetler, Life and Times, 243-45,48-55; Stoll, Sunshine, 328.

${ }^{196}$ Eicher, Childhood, 176-77.

197 Stoll, Sunshine, 337.

${ }^{198}$ Eicher, Childhood, 81,83-84.
} 
too much, and that for the sake of seekers and converts, Spanish should be used, not German. Conservatives countered that to lose German is to disconnect future generations to their religious heritage and the North American Amish body, amounting to a move toward joining the AmishMennonites. ${ }^{199}$

By that autumn, a resolution was allegedly reached. Monroe wrote a simple, short statement in his diary on the matter: "we, as a brotherhood, decided [to conduct services in German] at least [once a month]," and Spanish would be the norm. ${ }^{200}$ Within a short time, German was further relegated, this time to just some evening services. ${ }^{201}$

Monroe's succinct note leaves the impression that the language change was without fuss, which could not be further from the truth. The German language is nearly as much a boundary of modern Amishness as not driving automobiles. If German were discontinued, children would not know it. Without knowing the language of the in-group, it was improbable that the next generation would remain Amish. And so, in August 1975, in the heat of the language dispute, the conservatives delivered to the ministry an ultimatum: if shifts away from Amishness continue, they will leave. While the letter was put in a relatively gentle way, it was also for the Amish unusually direct, bringing the community to a fork in the road with its conclusion:

[W]e are confident that you want what is best for the church. At the same time, we as parents and laymembers also have a responsibility to our children and to the church... we do not want to be caught in a current that would sweep us ever nearer the world. ${ }^{202}$

The letter contained four points. First, the two camps, despite many open conversations about differences, failed to achieve single-mindedness. Inversely, the departing of Stephen Stoll drove a deeper wedge: the progressive camp continued with changes while the conservative camp dug in harder. Second, the progressive party continues to push for the acceptance of the tractor. To allow tractors is inconsistent with one of the community's original intents: to exhibit practical, small-scale agricultural practices that the Hondurans could emulate. Also, the tractor would likely be used for transportation, leading to allowing trucks. Third, some commonly fraternize with (and lean toward) the Amish-Mennonites, evident by all of the visiting exchanges with them. Furthermore, Richard Hochstetler felt the Costa Rican Beachy churches should assist with the San Marcos outreach effort. ${ }^{203}$ Fourth, and in the most detail, the move away from German is a move away from being Amish. ${ }^{204}$

These four points were not the only issues but a strategic sample from an intertwined bundle. In his diary, Joseph had noted the acceptance of "saved by grace alone" jargon of

\footnotetext{
${ }^{199}$ Interview with Vernon and Katie Schmucker; Stoll, Sunshine, 369.

${ }^{200}$ Hochstetler, Life and Times, 302.

${ }^{201}$ Eicher, Childhood, 218-19.

${ }^{202}$ Stoll, Sunshine, 370.

${ }^{203}$ Ibid., 362

${ }^{204}$ Ibid., 369-0.
} 
Protestant authors and the double standard for ethnic Amish and converts in dress. ${ }^{205}$ Evidently, the way was also being prepared to relax dress standards. For example, some women were going around without a cape. When Ruth Eicher confronted one of them, the lady responded by calling upon the liberty found in Christ. ${ }^{206}$ The theological leanings of some were more-and-more toward evangelical outlooks.

Almost two months after the letter had been submitted, Monroe and Richard met with the signers. Monroe felt that the letter put all responsibility on the progressives for introducing new changes, whereas some conservatives - notably Sammy Eicher with his machine shopintroduced new innovations in their own right. Sam offered to sell his machine shop, but the ministry did not match the ante. On the contrary, Monroe made it known that the way was now clear to allow tractors: on a recent trip to North America, he counseled with New Order Amish leaders, who agreed with Monroe that an exception for Honduras could be had for tractors given the paucity of work horses. ${ }^{207}$ The meeting failed to bring about peace.

Without sympathy from the ministry, the conservatives quietly resigned to the prospect of moving. Aylmer's Honduras Concerto had concluded-almost. A coda took the conservatives by surprise in 1976, offering a beam of ultimately dashed hopes that postponed departure. In the spring of 1975, Richard Hochstetler moved to San Marcos indefinitely, ${ }^{208}$ leaving another opening on the minister's bench. The ministry had twice proposed an ordination in 1975; the conservatives rejected it, but for peace's sake agreed to go along with communion. Now an ordination was urgent, yet the church was ever-closer to a division, and this time, the conservatives were likely to stay back from communion. ${ }^{209}$

Indeed, through the winter and spring of 1976, conservatives, including Joseph Stoll, were contemplating a move elsewhere in Honduras. Under the guise of taking a journey to visit the wilderness commune of New Palestine, he and Mark Stoll went east toward the Honduran frontier, eyeballing potential new settlement areas. They reasoned that for the Amish to return to North America would not only be a waste of agricultural and business skills learned over several years but would also be a missed opportunity to get a foothold in Latin America, should the plain people ever need to escape North America. Joseph contemplated whether they could get an Old Order Amish bishop to help get started. ${ }^{210}$

Yet, in North America, Amish anxieties about cultural and political changes were softening. In the United States, 1-W service had ended and the 1972 Wisconsin v. Yoder case gave Amish much autonomy in schooling matters. In Canada, legislation was adopted in 1974 that exempted self-employed Amish from payment into social security.

\footnotetext{
${ }^{205}$ Ibid., 362-63.

${ }^{206}$ Eicher, Childhood, 218-19.

${ }^{207}$ Stoll, Sunshine, 371; Eicher, Childhood, 218-19.

${ }^{208}$ Hochstetler, Life and Times, 315; Stoll, Sunshine, 336-37.

${ }^{209}$ Stoll Sunshine, 386.

${ }^{210}$ Ibid., 387-98.
} 
Ultimately, the trip to New Palestine proved unsuccessful; Joseph and Mark returned to Guaimaca convinced that - considering altitude, climate, creeks, soil quality, bus routes, land prices, clear land titles, irrigation possibilities, and distance to town - no other "Guaimacas" were out there, so they refocused their efforts on salvaging the Guaimaca church. In mid-April, Joseph Stoll and his young brother-in-law John Martin visited several progressive men to try to articulate their concerns. After this visit, Monroe called a colony-wide "heart to heart" two days later. The two meetings, although not hammering out any concrete change of direction, at least left the conservatives feeling comfortable enough to participate in a service for communion and voting for candidates for the lot. ${ }^{211}$ The service was to be conducted in German with Spanish translation. ${ }^{212}$ Lots would be drawn the following Tuesday. Five were in the lot: two liberals (Danny Stoltzfus and David Peachey), a moderate (Emil Helmuth), and two conservatives (Joseph Stoll and John Martin), the lot falling on John Martin. ${ }^{213}$

John Martin's ordination provided some hope that "this church might yet survive as a stable, well-balanced, conservative-minded congregation," 214 and events unfolded that summer as if it would. John's first sermon was spoken with "conviction and [he] did not hesitate to express exactly how he feels." ${ }^{215}$ A new administrator, Eric Kraly, came to work at the children's home to replace Danny Stoltzfus, more agricultural and personal shipments from North America came in, and Ira Stoll bought the farm of Richard Hochstetler, who had moved to San Marcos. ${ }^{216}$

But the church would not survive as Amish, and this became quickly evident. Upon the Nappanee folks, "the hammer [of God] had fallen hard" with John Martin's ordination, wrote Jerry Eicher, who reserved his autobiography's most biting words against the Nappanee clan for this moment. John Martin was a staunch conservative, but lacked the diplomacy and presence of Joseph Stoll. His Spanish was broken. The liberals punished John Martin for being ordained, wrote Eicher, pushing him to learn Spanish and get involved in outreach. "He looked subordinate and acted subordinate. To the liberals, that was, of course, the proper position for a conservative. He was a man who needed to learn their ways." ${ }^{217}$ By September, Joseph-for one-was making a trip to Aylmer to confer with the church about moving back; "a few issues came up," he wrote, and by November he was making plans to return. ${ }^{218}$

Ultimately, Joseph and others felt "pressured to leave [...] due to the severe church drift." ${ }^{219}$ Joseph Stoll agreed to sell his farm to the colony, although he felt the offer, \$13,500, seemed low. Alva and Bertha Stoll sold their farm to Leroy Hochstetler, and in April 1977, the

\footnotetext{
${ }^{211}$ Ibid., 399-400.

212 Hochstetler, Life and Times, 315.

${ }^{213}$ Eicher, Childhood, 234; Hochstetler, Life and Times, 315-16.

214 Stoll, Sunshine, 400.

215 Ibid.

${ }^{216}$ Hochstetler, Life and Times, 315; Stoll, Sunshine, 401,10.

${ }^{217}$ Eicher, Childhood, 234-35.

${ }^{218}$ Stoll, Sunshine, 413,20.

${ }^{219}$ Joas and Lillian Yoder, ed. Who Is Who in the Budget? (Middlebury, IN: Who Is Who, 2000), 31.
} 
Stolls with their six children left by public bus. Several days later, Joseph Stoll's family of 13 also left by public bus. With finality, Joseph wrote, "Though our convictions have not always been the same, I am glad to say that we can leave with a mutual feeling of affection and respect." 220 (Joseph would exchange letters with some of the Nappanee people in the months and years thereafter.)

In September 1977, after selling his farm to a non-Amish man, Sammy Eicher and family left. Though his wife Ruth wanted to return to Aylmer, Sammy resisted and moved the family to the New Order community of Belle Center, OH, to where Bishop Wally Byler had recently moved. They returned by airplane. ${ }^{221}$ In the spring of 1978, Peter Stoll's widow Anna, family, and Mark Stoll's family also moved to Aylmer, and John Martin's, leaving around the same time, had a short foray in Bowling Green, MO, before moving on to Aylmer. ${ }^{22}$

In August, the children's home had to deal with a sizeable hole when administrator Eric Kraly and family and Lydia Mae Hochstetler departed. "It is not to be denied that like in any organization where humans are involved," pens David Peachey in The Budget, "that in the past mistakes have been made but that is defeat if one does not rise up and trys [sic] again." 223

"It seems the more people who leave, the more unsettled the situation becomes," wrote Joseph in a letter to Ira Stoll that month. ${ }^{224}$ Ira would soon join his Freundschaft in Aylmer as well; the Daniel "Junior" Miller family also moved back to North America, in two New Order settlements before moving to Aylmer in 1984. By the summer of 1978, the community had not only tolerated tractors ${ }^{225}$ but also bicycles, while the truck was under discussion. Bicycles were the first convenience allowed after Monroe announced that majority vote would direct future changes (the Amish normally require a unanimous vote). ${ }^{226}$

And yet, despite this alteration in policy that would break some stalemates, Bishop Monroe Hochstetler soon felt estranged from his church. Near the end of his autobiography, he states abruptly that two schools of thought have emerged; to this point, he gave little hint that the settlement was faltering. While he felt responsible as bishop, he also felt it was necessary to protect his children, as the church wanted to go beyond his personal convictions. ${ }^{227}$ In November 1978, two moderate families, Emil Helmuth and Bishop Monroe Hochstetler, left for the New Order Amish church in Salem, IN, where Lydia Mae Hochstetler and Ada Martin had moved to and were working to establish another children's home. Monroe hired Mennonite Joseph Overholt, who had spearheaded several infamous choir tours through Central America on

\footnotetext{
${ }^{220}$ Stoll, Sunshine, 435-39.

${ }^{221}$ Eicher, Childhood, 251.

${ }^{222}$ Stoll, Sunshine, 443.

${ }^{223}$ David Peachey, “Guaimaca F.M., Honduras C.A.," The Budget, August 1978, 13,30. HHL Honduras box.

224 Stoll, Sunshine, 432,46.

${ }^{225}$ Peachey, "Guaimaca F.M., Honduras Ca," 7. HHL Honduras box.

${ }^{226}$ Eicher, Childhood, 232-34.

${ }^{227}$ Hochstetler, Life and Times, 380-87; Stoll, Sunshine, 446.
} 
antiquated busses, to take them to Indiana in his 1950s refurbished Greyhound bus (the trip, Monroe writes, was a doozy; it had trouble making hills and broke down in Texas).

What pushed the bishop out of the settlement? He was of those who owned a tractor. However, if Monroe insisted on no other line of Amishness, he did insist on a prohibition against automobile ownership, the final and ultimate line of modern Amishness. Those wanting automobiles rationalized that since the San Marcos mission was a several hour walk back in, "it's not practical to insist on horse-power and hire the motor power," wrote a later settler in The Budget. Richard Hochstetler especially felt the distance strain, and pressed for automobiles. ${ }^{228}$ "[S]o they made use of automation for travel also. This [...] did not please everyone," and if measured by all who had been at the settlement one time or another, one could add that it did not please most everyone. But the minority interested in vehicles had a stronger foothold with the departure of large swaths of the Stoll clan. "Some had good businesses," continues The Budget scribe, "but took their loss and sold out and moved away." 229 Upon Monroe's departure, the remaining families under the leadership of ministers Richard Hochstetler and Vernon Schmucker adopted trucks, thus severing their affiliation with the New Order Amish. All-in-all, 14 of the 20 families moved back to North America by 1978.

\section{In Reflection}

In Honduras, unrest was evident in the very first years and persisted right up until the church allowed trucks in 1978, which effectively severed the settlement from Amish fellowship. By that time, over half of the original families had left. However, while the Amish settlement failed, the settlement itself continued on. What remains of the Honduras Amish effort today is reflected in (a) the Crossroads church at Guaimaca, a charismatic, theologically conservative affiliation out of Holmes County, $\mathrm{OH}$, and (b) four Mennonite Christian Fellowship churches (a conservative yet outreach-oriented branch of Amish-Mennonite) including the San Marcos church, the Cualote church (a relocation of the Guaimaca church not too far from San Marcos), and two nearby outreaches. ${ }^{230}$ The original New Order Amish affiliation of the settlement lasted right at a decade.

In a supplemental booklet to his larger volume The Amish in America: Settlements That Failed, 1840-1960, historian David Luthy identifies nine common reasons Amish settlements fail. He illustrates each example with an interesting case, such as the Pawnee City, Nebraska, settlement conflict with school authorities and the Stuarts Draft, VA, settlement's change of affiliation. ${ }^{231}$ Each story is both representative of other cases and yet fascinating in its own right. Certainly the story of the failed Honduras settlement contains such a recipe: it includes details

\footnotetext{
${ }^{228}$ Interview with Vernon and Katie Schmucker.

${ }^{229}$ John Renno, "Danville, Pa," The Budget, September 1988, 3,7. HHL Honduras box.

${ }^{230}$ Allan Miller, ed. The Origin of the Fellowship Churches (Gap Mills, WV: Yoders' Select Books, 2004), 31 33,58-59,72-84

${ }^{231}$ David Luthy, Why Some Amish Communities Fail: Extinct Settlements, 1961-2003 (Aylmer, ON: Pathway Publishers, 2003[1997]).
} 
that are strikingly representative of Amish church conflict leading up to reaffiliation, yet also draws in an audience inquisitive about how Amish would fare in Central America. The success of three published memoirs about the settlement alone attests to people's curiosity.

But what is at the root of such curiosity? Notably, these Amish were testing the limit of one long-standing Amish problem solving device: migration. ${ }^{232}$ Long a community repertoire of action exercised by the Amish, migration has been nonetheless exclusively ${ }^{233}$ exercised within North America's confines since Amish arrived on its shores. ${ }^{234}$ Thus, the Honduras settlement was precedent-setting. Can the familiar Amish pattern of migration and community reestablishment be pushed outside North America?

No, at least if not measured by this attempt (and three simultaneous Paraguayan attempts). What, then, does this case have to teach us about why an international settlement is more prone to failure than a North American attempt? The settlers certainly lacked nothing by way of sufficient families, a full ministry, a government that left them alone, and good agricultural land and markets (albeit their farming and marketing required some modifications). Furthermore, measured against the types of places that sustain Amish populations, Guaimaca was a good fit on nearly all accounts: low population density and growth, proximity to a small town and market, and infrastructure for small scale agriculture. One blaring exception is vicinity to another Amish settlement, ${ }^{235}$ yet the Guaimaca Amish suffered neither a dearth of visitors nor unfulfilling intra-community social relations in spite of Ordnung differences.

The many practices that define the Amish have the most relevance within the context they were forged, basically, North America. Amish have no bent toward isolation like their Russian Mennonite cousins. They depend on services and people from the host country: roads, equipment rental, taxis, telephones, grocery stores, postal service, and so forth. These very conveniences, services, technologies, and symbolic markers are also the focus of restrictions intended to solidify the church community and resist assimilation.

In Guaimaca, the Amish found themselves exposed to a new material reality, a variable by-and-large absent in North American settlement failures. The horse and buggy, an icon of Amishness in North America, did not conjure up the same romanticism of a time long past for Hondurans, and neither did black felt hats, bonnets and aprons, and agrarianism. In North America, the Amish are recognized as separate yet upholding good ideals, and so they are treated

\footnotetext{
${ }^{232}$ Elmer Schwieder and Dorothy Schwieder, A Peculiar People: Iowa's Old Order Amish (Ames, IA: Iowa State University Press, 1975), Ch. 6; James Landing, "The Old Order Amish: Problem Solving through Migration," Bulletin of the Illinois Geographical Society 17, no. 2 (1975): 36-48.

${ }^{233}$ With the exception of a short settlement attempt in the 1920s just across the Mexican-American border. The Amish settlement quickly lost support of the sending community, likely because the region was a center of revolutionary activity. See Luthy, Settlements That Failed, 512-21.

${ }^{234}$ Reschly, Amish on the Iowa Prairie, 182-204.

${ }^{235}$ Cory Anderson and Loren Kenda, "What Kinds of Places Attract and Sustain Amish Populations?," Rural Sociology 80, no. 4 (2015): 490-91,500-02.
} 
accordingly. ${ }^{236}$ But what were symbols of Amish values crafted in response to a North American industrialized and urbanized context were up for redefinition in Honduras. In Honduras, Amish material possessions, houses, and occupations marked them as wealthy, not humble country folk. Yet, these practices were essential to maintaining their identity and association with North American Amish.

What especially pushed some Amish to question the Ordnung was an emerging evangelical outlook on mission. No strong precedent for a distinctively Old Order-style of mission existed, although Peter Stoll, a philosopher in his own right, appeared to be hammering one out before his untimely death. With his passing, a conceptual hole opened that an evangelical philosophy and mode of mission easily filled. Indeed, during the 1970s, Central America was the scene of major evangelical and Pentecostal advances, and the Amish could not have been blind to these changes around them.

The evangelical mode views bringing people to salvation through a verbal confession as the paramount need of humanity. Anything obstructing or distracting from this core mantra must be done away with, including — and especially_-seemingly arbitrary practices required of converts. With an emphasis on outreach, some Amish found it easy to view the Ordnung's many now-arbitrary practices and symbols as superfluous, if not also in the way. This shift of visionfrom matching the particular strengths of an Amish-type church to the material and religious needs of a specific culture, place, and time (a potential Old Order view of mission), to an aggressive effort to save anyone's soul with little regard to cultural nuances of the giver or receiver (an evangelical view of mission) - is captured clearly in a statement by Katie Schmucker: "We did not really expect or strive to live like the natives [...] it was not our expectation to lift the natives up to our standard, but to a higher standard"237 — hence, how they could view Amish restrictions on tractors and automobiles as both an arbitrary standard of Amishness not worth keeping and an acceptable step away from the standard of living of the their mission focus.

Any given Amish community may deviate in some areas without activating the slippery slope out. If not the many compromises, what may have helped this community fall away was the stigma placed on it from North America. The Aylmer leadership had never rescinded their skepticism of this effort, and the Nappanee ministers left their settlement estranged. No Old Order bishop offered oversight for the settlement, and the group found assistance from a bishop who had been involved in the far-reaching New Order schism. The group's relative autonomy from the day-to-day social pressure Amish families, districts, and communities exert on one another in North America - and the fact that they had little to lose in changing more given uncertain relations with North America-provided ripe conditions for re-affiliation, especially when rubbing shoulders with Amish-Mennonites in neighboring countries.

\footnotetext{
${ }^{236}$ Susan Trollinger, Selling the Amish: The Tourism of Nostalgia (Baltimore, MD: Johns Hopkins University Press, 2012).

${ }^{237}$ Interview with Vernon and Katie Schmucker.
} 
If anything, the question, "Why did it take nearly a decade to switch?" should be advanced over, "Why did the settlement fail to remain Amish?" The answer to this first question is that a sizeable minority of Aylmer-allied families rejected moves toward realignment. The Stolls in particular were not only self-reflective in their conservatism, evidenced by their sheer propensity for writing, teaching, and coordinating, they also accepted many Amish traditions without demanding rationale; Amish practices are a means of anchoring the religious community's being, and that is justification enough to keep them. Even though active in outreach, the Stolls "still wanted to keep those Amish traditions," recalled Katie Schmucker, "did not want to lose the aprons, even the little girls had to wear them. What they did not want is to lose face with the people at home." ${ }^{238}$ While slightly outnumbered - not just in families, but also on the ministers' bench — the Stolls' desire to remain Amish delayed the transition.

The moderate and progressive families, on the other hand, were products of their environment: alienated from North American Old Order-ism and living in a place where longstanding mechanisms and markers of Amishness required inspired reapplication, they found that "being Amish" was tedious and cumbersome, especially when weighed against outreach-focused causes first championed by Peter Stoll, but eventually more indicative of evangelical mission. Peter Stoll's outlook on missions involved an embrace of Amish-ness; he managed to internally reconcile the tensions between identification with a separatist community and outreach-focused mission work. The families from Nappanee, on the other hand, had run up against the Amish establishment when starting Bible studies and "preaching the new birth," a familiar conflict in many mid-century Amish settlements. Now having escaped to a context where extra effort was needed to retain Amish practices, they preferred to concentrate on core doctrines stressed in the evangelical awakening that characterized their original withdrawal from the Nappanee Old Order Amish.

Through all of the differences among the Amish over what to hold and what not to hold, the opinions and feelings of the few converts to the Guaimaca church are noticeably absent in all three autobiographies of the Amish period. One could assume that the Hondurans would not like anything the Amish do that is different from their own ways: they should not have to wear Amish clothes, learn the German language, and conform to Amish technology restrictions. One could also assume that they would not seek to be Amish if they did not actually want these very same things, as irreconcilable as it may be to onlookers' minds.

Both assumptions would be an oversimplification of the truth and both would probably be over-thinking the reality of the matter. Push come to shove, the differences among the Amish were strictly internal types of conflicts, enacted in ways reminiscent of North American Amish church conflicts, especially those of the mid-century mission and purity movements among the Amish. The extent to which the geographical location-both secular Honduran culture and the tropical climate - incidentally created stress on Amish practices that otherwise would not have

${ }^{238}$ Ibid. 
been and the extent to which the migrants were already on paths destined to collide cannot be measured out with precision, although both factored in to an extent actual consideration for seekers did not. In this respect, the failure of Guaimaca as an Amish settlement is little different than the failure of settlements many times over in North America.

But the story of the Honduran Amish is not fascinating just because of its international context; the settlement hosted one of the most eccentric family clans in the twentieth century Amish world, the Stolls. Worth noting is that the Stoll clan, even prior to the arrival of most families and the two ministers from Nappanee, had already made changes in Honduras that Aylmer looked apprehensively upon. It would be unfair to peg the Nappanee folks with either the initial push for change or the only originators of it. What if the Nappanee families had never come? Would the settlement have struggled similarly, within their clan? What if it were the Stolls who were ordained and not Nappanee families, by-and-large? Possibly, the Stolls may have led the impressionable young families along a solidly Amish path. It is, after all, doubtful that the Nappanee families would have left if the community did not go liberal enough. But then again, some of the Stolls could very well have turned out to be the ones experimenting with church in such a way as to alienate North American Amish, just in eccentric, and not familiar (read: evangelical) ways.

When Joseph Stoll reflects back on the Honduras years, he writes that "in real life the [international] experiments haven't been convincing [...] [Immigrants] have been the more adventuresome type, less stable and less conservative than the ones that do not go." ${ }^{239}$ While his comments could unthinkingly be placed on the Nappanee families, it was the Stoll clan that were the "adventuresome" "less stable" type, who had found themselves at odds with the Daviess County Amish, taken an interest in the Sleeping Preacher teachings, attempted a set of experimental settlements in Michigan and one extremely tentative outreach-focused church in Ohio, then pioneered the first foreign-instigated Canadian settlement in over a century, and finally established a publishing company without past record of a successful, persistently Amishsponsored press (a record it went on to set). These were the ones who saw too little incentive to move 1,100 miles to Prince Edward Island when laying that option alongside Honduras.

What is very possible is that the largely unreflective, cookie-cutter path the Nappanee families took to leave the Amish and become Amish-Mennonite served as a negative reference to the reflective Stolls, who solidified a stronger commitment to Old Order-ism than ever. The clan's immeasurable contribution to helping build Aylmer's sense of identity, connectedness, and religious purpose through the 1980s — and through the shocking departure of their bishop brother Elmo, who left to attempt yet another experimental community — is in part, if not largely, an outcome of their successful, albeit serendipitous, sojourn in Honduras.

In the Honduras story, the progressive Nappanee families and their two Pennsylvanian

${ }^{239}$ Stoll, Sunshine, 442. 
counterparts and the sprinkling of moderates like Bishop Monroe Hochstetler are not the fascinating variable in the Honduras story. Their lives have followed the script of many other young liberal ministers, non-committal moderate bishops, and fence-pushing laymen across Amishdom for at least a century. The only difference is the Latin flavor of their case. The real anomaly in the Honduras Amish story is the Stoll clan and their willingness to tinker with fungible Amish repertoires in ways unorthodox even to stand-by Amish unorthodoxies. The real plot of the Honduras story is not Aylmer vs. Nappanee or conservative vs. moderate / liberal or Amish vs. Honduras, but man vs. self, or Stolls vs. selves, a final step of a long wandering in the wilderness, deciding after three generations, once-and-for-all, to subject their visionary dexterity to the usefulness of to a familiar Old Order-ism. This could have been the drafting of a real, tangible Old Order mission ideology. However, it did not transpire. Instead, because of this vision, they have contributed to building the Aylmer settlement into one of the most well-known small Amish settlements across the plain Anabaptist spectrum, renowned for its desire to call Old Order Amish (and Old Order Mennonites) to high moral standards without losing the "Old Order."

\section{A Window in Time?}

Could an Amish settlement yet be on the horizon for Latin America? By the time the Stolls saw that, realistically, little hoped remained for keeping Guaimaca Amish, they were entertaining relocation within Honduras, establishing an Amish church elsewhere. (After Joseph Stoll left, Monroe, too, entertained the idea of settling elsewhere within Honduras, but with new people.) ${ }^{240}$ Consequently, late in the game, the Stolls had evidently cemented their commitment to Amish thought and picked up Peter Stoll's vision of Old Order-style mission. And a good chance exists that a new Honduran settlement would have affiliated with the Old Order, rather than New Order, if they could find an Old Order bishop to provide oversight. Their thinking was moving more in an Old Order direction, not the tedious amalgamation of Old Order-ism and evangelicalism that characterizes the New Order Amish. That moment, then, was the obvious juncture at which to establish a durable Old Order Amish church in Central America, one that had worked through its cross-cultural kinks, had learned what kind of vision (and what kind of Amish) makes a Latin Amish church, and had only the randomness of certain events-like deaths of key personalities and the landing of the lot in ordinations - to contend with.

After all, the largest hurdle Amish deal with in establishing an international settlement is the sheer distance, and the Stolls were already there. Back in North America, the pleading to not leave is great: "Why, why move so far away?!" cry the Freundschaft. And really, why? At the time of the Honduras settlement, two legitimate answers met that question.

First, the needs of the globe are great. Peter argued that the Amish have the right level of technological practice and standard of living to be of more use in Central America than North

${ }^{240}$ Hochstetler, Life and Times, 384-86. 
America. Peter actually proposed a form of mission that was not peppered with evangelicalismthe force that had long undercut Amish church order-but found a way to match the Amish model of church in a self-conscious way to the betterment of people in a specific culture:, exhibiting moral practices, demonstrating new agricultural techniques, nurturing and caring for neglected children, and providing work for locals. Amish Christianity as practice and everyday life could better be understood and adopted in developing countries out of touch with Western Enlightenment style thinking, a mode of thought that had given birth to American evangelical theology with its conceptual emphasis and that continues to upset generations of Old Orders in North America.

Today, whether among the Old or New Order Amish, when murmurings start growing for mission and outreach, the trend is unquestionably toward an evangelical mode. Plain circles are so steeped in evangelical mission thought by now that no other modifier to "mission" is known. Hence, evangelical and mission have become synonymous. One sign of this is the sheer omnipresence of Christian Aid Ministries, an agency with widespread conservative and Old Order backing that doles out a combination of material aid and non-sectarian religious messages. ${ }^{241}$ Additionally, Anabaptist Foundation, an anonymous donation service, boasts of large amounts of money coming from Old Order Mennonite and Amish contributors for AmishMennonite mission programs, suggesting many Old Orders harbor secret leanings toward evangelical mission. ${ }^{242}$ For an Old Order church to get directly involved in foreign missions immediately suggests that an evangelical (conservative) future is ahead. Evangelical mission makes Amish standards seem irrelevant and culturally insensitive: "There are more important things than trying to uphold a bunch of petty standards!" Yet, those standards make the Amish offering viable for a conceivably Old Order style of mission but are undermined when evangelical mission is grafted in. Consequently, the argument for "mission" will today gain no traction in an Old Order Amish church in response to the question, "Why move so far away?"; to go on a mission is equated with accepting evangelical programs and theologies, which is just a nice way of saying goodbye to the Amish.

The second answer Peter gave to this question is that North America is falling apart, culturally, economically, and politically; the Amish should get a foothold in another country in the event mass emigration is needed. The stresses Amish faced in mid-century America may very well have been unprecedented and not faced at that level since. For a moment in time, fleeing North America into the haven of the wilderness in Latin America seemed an attractive option. With resolution on many governmental issues and a mainstream conservative back-peddling through the 1970s and 1980s, the Amish needed only learn to tolerate the depravity into which mass culture was continually sinking. The government had basically backed off and the economy was stable. To prompt Peter's "foothold" answer again among future Amish, a societal crisis on

\footnotetext{
${ }^{241}$ Jennifer Anderson and Cory Anderson, "Conservative Mennonite Storybooks and the Construction of Evangelical Separatism," Journal of Amish and Plain Anabaptist Studies 2, no. 2 (2014): 245-77.

${ }^{242}$ Noted in the 2016 minutes of the Beachy Amish-Mennonite ministers' meeting, pg. 10.
} 
par or even deeper must happen, and happen suddenly.

With neither rationale to move so far away available since, the likelihood of future international Old Order Amish settlements seems a distant prospect without something changing. To get the Amish to move out of North America again, either a new expression of mission that can distance itself from current expressions must arise or the church must face such heavy external stress that migration is seen as the only option. Then may an international Amish settlement arise again. In all likelihood, the Amish will instead continue flexing migration destination precedents in more gentle ways, to new states, provinces, and North American regions (e.g. Maine and the Canadian maritime, the Great Plains and the Rocky Mountains, and the Deep South), all the while in-filling existing regions of settlement. ${ }^{243}$

In the midst of these dim prospects for an international Old Order church, the New Order Amish have recently undertaken a joint effort in Bolivia and Argentina. Bishop Jake Beachy, Bishop Jonathan Miller, and Minister Roy Kline visited Bolivia in July 2014 and stated their findings in a two-page report. ${ }^{244}$ Unlike the Honduras attempt, the outreach focus falls squarely on Old Colony Mennonites. An Old Colony couple who had converted to the Old Order Amish in Aylmer, ON, appealed to the New Order Amish for assistance in reaching out to their families in Bolivia; Aylmer declined oversight since they do not permit plane travel. Simultaneously, an Old Colony Mennonite family in Mexico who had come to adopt some Amish practices was seeking to move out of Mexico and was considering Bolivia or Argentina. In investigating the Bolivian Old Colony Mennonites, the three investigators reported critiques very similar to critiques of their Holmes County Old Order Amish counterparts: not practicing the holy kiss, extremely formal church services, youth immorality, and leaders who are concerned but will not act. They stated their intention to require of converts nearly all markers associated with the Amish — horse and buggy use, the beard, and other standards - although name possible exceptions such as the hanging veil style women's covering and tractor farming.

"Why move so far away?" The New Orders may have developed a third response palatable to their tradition: resuscitate near-dead Old Order counterparts. The likelihood that evangelical mission will supplant their conservative practices is of course a real possibility. "The threat of people coming back from the Protestant mission field and becoming disillusioned with our faith has been a real threat to our view of missions" the report concludes. "Our involvement here, with unified church support, could be the area of outreach our churches never had." As soon as the Old Colony Mennonites are framed according to evangelical language - the need for new births, salvation experiences, and so forth - and not just a rectification of moral conditions through providing a lived alternative, the New Order international churches are likely to progress beyond Amishness. Then again, even if they keep evangelical thought out, proselytizing among cousin Anabaptists certainly cannot be equated with Peter Stoll's vision for mission in Honduras.

\footnotetext{
243 Anderson and Kenda, "What Kinds of Places Attract and Sustain Amish Populations?," 504-06.

244 "Fall 2014 Update and Facts on the Mennonites in Bolivia."
} 
If this international Amish settlement succeeds, it is not because they are trying anything newsuch as a distinctively Old Order version of mission - but because they are doing something very familiar in an otherwise totally new place.

\section{Endnote}

${ }^{1}$ Contact information: Cory Anderson, Department of Society and Environment, Truman State University, 100 E. Normal Ave, Kirksville, MO 63501; dranderson@beachyam.org

\section{Primary Sources}

Beachy, Lester. 2001. "Lyndonville, N.Y.” Pg. 17 in The Budget. Sugarcreek, OH.

Peachey, David. 1978a. “Guaimaca F.M., Honduras C.A.” Pp. 13,30 in The Budget. Sugarcreek, $\mathrm{OH}$.

—. 1978b. “Guaimaca F.M., Honduras CA.” Pg. 7 in The Budget. Sugarcreek, OH.

Pike County Amish Church. 1950. “Ordnung of a Christian Church.” Piketon, OH.

Renno, John. 1988. “Danville, PA.” Pp. 3,7 in The Budget. Sugarcreek, OH.

Schmucker, Vernon and Katie. 2013. Interview with authors. June 28, 2013.

\section{References}

Anderson, Cory. 2011. "Retracing the Blurred Boundaries of the Twentieth-Century 'Amish Mennonite’ Identity.” Mennonite Quarterly Review 85(3):361-412.

Anderson, Cory. 2016. "Religiously Motivated Migration." The Sociological Quarterly 57(3):387-414. http://dx.doi.org/10.1111/tsq.12139

Anderson, Cory, and Loren Kenda. 2015. "What Kinds of Places Attract and Sustain Amish Populations?” Rural Sociology 80(4):483-511. http://dx.doi.org/10.1111/ruso.12083

Anderson, Jennifer, and Cory Anderson. 2014. "Conservative Mennonite Storybooks and the Construction of Evangelical Separatism.” Journal of Amish and Plain Anabaptist Studies 2(2):245-77.

Andreoli, Eileen, and Judith Miller. 1998. “Aging in an Amish Community.” Nurse Connections 11(3):5-11.

Bailey, Martha, and William Collins. 2011. "Did Improvements in Household Technology Cause the Baby Boom? Evidence from Electrification, Appliance Diffusion, and the Amish." American Economic Journal: Macroeconomics 3 3(2):189-217. http://dx.doi.org/10.1257/mac.3.2.189 
Beachy, Alvin. 1954. "The Amish Settlement in Somerset County, Pennsylvania." Mennonite Quarterly Review 28(4):263-92.

Burgess, Ernest, and Harvey Locke. 1945. The Family. New York: American Book Co.

Cavan, Ruth Shonle. 1978. "Roles of the Old in Personal and Impersonal Societies." Family Coordinator 27(4):315-19. http://dx.doi.org/10.2307/583433

Cong, Dachang. 1992. "Amish Factionalism and Technological Change: A Case Study of Kerosene Refrigerators and Conservatism.” Ethnology 31(3):205-14. http://dx.doi.org/10.2307/3773527

Coulter, Maureen. Oct. 28, 2014 “Amish Communities Checking out Province.” The Guardian. Eicher, Jerry. 2013. My Amish Childhood: A True Story of Faith, Family, and the Simple Life. Eugene, OR: Harvest House.

Hiller, Harry. 1968/69. "The Sleeping Preachers: An Historical Study of the Role of Charisma in Amish Society." Pennsylvania Folklife 18(Winter):19-31.

Hochstedler, Rachel, and Susan Wheary. 2005. Treasured Memories: An Iowa Family in the Chaco. Wyandotte, OK: Rachel Hochstedler.

Hochstetler, Monroe. 2007. Life and Times in Honduras: Twenty Families Struggle in Honduras. Worthington, IN: Monroe Hochstetler.

Hoover, Peter. n.d. "Pure Church Movement." Detention River, Tasmania, Australia: Rocky Cape Christian Community. Unpublished paper.

Huntington, Gertrude Enders. 1981[1976]. "The Amish Family.” Pp. 367-99 in Ethnic Families in America, edited by Charles Mindel, Robert Habenstein, and Roosevelt Wright, Jr.. New York, NY: Elsevier.

Keim, Albert. 1961. "History of an Amish Community: Pike County, Ohio, 1949-1953." Paper in Mennonite History and Thought. Harrisonburg, VA: Eastern Mennonite University.

Kline, Edward, and Monroe Beachy. 1998. "History and Dynamics of the New Order Amish of Holmes County, Ohio." Old Order Notes (18):7-19.

Landing, James. 1975. "The Old Order Amish: Problem Solving through Migration.” Bulletin of the Illinois Geographical Society 17(2):36-48.

Luthy, David. 1986. The Amish in America: Settlements That Failed, 1840-1960. Lagrange, IN: Pathway Publications. 
Luthy, David. 2003[1997]. Why Some Amish Communities Fail: Extinct Settlements, 19612003. Aylmer, ON: Pathway Publishers.

Martineau, William, and Rhonda MacQueen. 1977. "Occupational Differentiation among the Old Order Amish.” Rural Sociology 42(3):383-97.

Miller, Allan (ed). 2004. The Origin of the Fellowship Churches. Gap Mills, WV: Yoders' Select Books.

Nolt, Steve. 2001. "The Amish 'Mission Movement' and the Reformulation of Amish Identity in the Twentieth Century." Mennonite Quarterly Review 75(1):7-36.

Penner, Heinrich, John Reimer, and Leonard Reimer (Eds.). 2008. Spanish Lookout since 1958: Progress in Action. Spanish Lookout, Cayo, Belize: Spanish Lookout.

Pride, Richard. 2003. "Elmo Stoll and the Christian Community at Cookeville." Border States: Journal of the Kentucky-Tennessee American Studies Association (14):36-49.

Regehr, T.D. 1995. "Relations Between the Old Order Amish and the State in Canada." Mennonite Quarterly Review 69(2):151-77.

Reschly, Steven D. 2000. The Amish on the Iowa Prairie: 1840-1910. Baltimore, MD: Johns Hopkins University Press.

Schwieder, Elmer, and Dorothy Schwieder. 1975. A Peculiar People: Iowa's Old Order Amish. Ames, IA: Iowa State University Press.

Stoll, James, and Carolyn Stoll. 2014. The Road to Aylmer: Secrets of an Amish Life. Mr. James Stoll.

Stoll, Joseph. 1996. Sunshine and Shadow: Our Seven Years in Honduras. Aylmer, ON: Joseph Stoll and Family.

Stoll, Joseph. 1997. The Amish of Daviess County, Indiana. Aylmer, ON: Joseph Stoll.

Stoll, Joseph. 2005a. "How the Amish Chose Honduras [Part I]." Pp. 6-7 in Plain Interests.

Stoll, Joseph. 2005b. "How the Amish Chose Honduras Part II." Pp. 10-11 in Plain Interests.

Stoltzfus, Victor. 1973. "Amish Agriculture: Adaptive Strategies for Economic Survival of Community Life.” Rural Sociology 38(2):196-206.

Thomson, Dennis. 1993. "Canadian Government Relations." Pp. 235-48 in The Amish and the State, edited by Donald Kraybill. Baltimorew MD: Johns Hopkins University Press.

Trollinger, Susan. 2012. Selling the Amish: The Tourism of Nostalgia. Baltimore, MD: Johns Hopkins University Press. 
Wagler, David. 2014. My Stretch in the Service (Civilian Public Service) and the Next Seven Years. Aylmer, ON: Wagler Books.

Wagler, Ira. 2014. “The Sons of Albert Stoll.” Retrieved Dec. 29, 2015 (irawagler.com/?m=201406).

Waldrep, G.C. 2008. "The New Order Amish and Para-Amish Groups: Spiritual Renewal within Tradition." Mennonite Quarterly Review 82(3):395-426.

Wittmer, Joe. 1971. "Cultural Violence and Twentieth Century Progress.” Practical Anthropology 18:146-55.

Yoder, Joas and Lillian (eds). 2000. Who Is Who in The Budget? Middlebury, IN: Who Is Who.

\section{Appendix 1: Timeline for the Guaimaca, Honduras, Amish Settlement}

1968 Dec $\quad$ Families 1 and 2: Peter \& Anna Stoll (plus 5 children) and Alva \& Bertha Stoll $(+2)$ of Aylmer arrive in Honduras

\begin{tabular}{ccc}
\hline 1969 July & $\begin{array}{l}\text { Family 3: Samuel \& Ruth Eicher (appx. +5) of Aylmer arrive in Honduras } \\
\text { July }\end{array}$ \\
El Salvador drops several bombs on Honduras without much damage; \\
among targets was the sawmill at Guaimaca, which was missed \\
Families 4 and 5: Joseph \& Laura Stoll (+8) and Deacon Stephen \& Katie \\
Stoll (approximately +6) of Aylmer arrive in Honduras
\end{tabular}

1971 Jan

Family 11: David \& Miriam Peachey $(+5)$ of Selinsgrove, PA, arrive 
Feb Mary Stoll, daughter of Peter, returns to Aylmer and marries David Luthy the next month

Mar Ordnung deliberations are underway

June Second Wally Byler visit. He conducts communion. Monroe Hochstetler is ordained minister (Joseph Stoll and David Peachey also in the lot)

Aug Catholic priests incite squatters to occupy land of large holders; a wealthy land owner murders a priest, and the government tortures him into confession

Ministers admonish laity to live up to Ordnung commitments

Oct Peter Stoll dies suddenly of a heart attack

Nov Family 12: Daniel “Junior” \& Sylvia Miller $(+11)$ from Nappanee, IN, arrive in Honduras

1972 Feb Third and final Wally Byler visit. He conducts baptisms and communion. Monroe Hochstetler is ordained bishop.

April Family 13a: John Martin and sisters Lizzie and Ada from Pilgrimage Valley, Belize, arrive in Honduras

May $\quad$ Family 14 / Wedding 1: Ira Stoll (son of Albert in Belize) and Lizzie Martin; they remain in Honduras

July $\quad$ Family 15 / Wedding 2: Abner Stoll (son of Peter) and Polly Anna Troyer (a school teacher); they remain in Honduras

Oct Miriam Peachey (Mrs. David) dies from cancer. David never remarries.

1973 Winter Height of deliberations over clothing standards

Feb Wedding 3: Joseph Wagler (son of David of Aylmer) and Iva Mae Hochstetler (daughter of Monroe); they move to Aylmer

Opening of the "Spanish school" for local children who otherwise would remain illiterate, with Mark Stoll as teacher

Sept Family 13b / Wedding 4: John Martin and Sarah Stoll (son of Peter); they remain in Honduras

Oct Departure 1: After months of contemplation, Stephen Stoll decides to return to Aylmer

Nov $\quad$ Family 16: Alvin \& Edna Miller (+2) from Nappanee, IN, arrive in Honduras

Dec Bible classes begin at San Marcos, on the instigation of Richard Hochstetler and Monroe Hochstetler

1974 Feb The Stephen Stoll family return to Aylmer

April Family 17: Daniel and Sadie Stoltzfus (childless) from Pennsylvania arrive in Honduras in to work as the children's home administrator

June San Marcos work expands with the building of a house and the holding of regular services 
Sept Hurricane Fifi strikes Honduras and the Amish begin relief work on the north coast, putting the San Marcos effort on hold

\begin{tabular}{|c|c|c|}
\hline \multirow[t]{4}{*}{1975} & Spring & $\begin{array}{l}\text { The Richard Hochstetler family, after concluding relief work in northern } \\
\text { Honduras, moves permanently to San Marcos. The Alvin Miller family } \\
\text { joins him }\end{array}$ \\
\hline & Summer & Use of Spanish comes to dominate church services \\
\hline & Sept & Conservatives write letter of concern to the ministers \\
\hline & Nov & Ministers respond unfavorably to letter \\
\hline \multirow[t]{6}{*}{1976} & March & Meeting held to try to move forward with an ordination and communion \\
\hline & April & Mark and Joseph Stoll scout for new settlement sites in eastern Honduras \\
\hline & & $\begin{array}{l}\text { Joseph Stoll and John Martin share concerns with several liberal families. } \\
\text { Monroe Hochstetler responds with a colony-wide meeting that gives } \\
\text { conservatives some hope. }\end{array}$ \\
\hline & April & Communion held and John Martin ordained minister \\
\hline & Spring & $\begin{array}{l}\text { Family 18: The Eric \& Leah Kraly family arrive in Honduras to replace } \\
\text { Daniel Stoltzfus as administrator at the children's home } \\
\text { Departure 2: Daniel Stoltzfus family returns to Pennsylvania sometime } \\
\text { within a year of Eric's arrival }\end{array}$ \\
\hline & Autumn & Joseph Stoll visits Aylmer to consider logistics of moving back \\
\hline \multirow[t]{6}{*}{1977} & Jan & $\begin{array}{l}\text { Family } 19 \text { / Wedding 5: Mark Stoll (son of Peter) and Dora Miller (daughter } \\
\text { of Daniel "Junior"); they remain in Honduras }\end{array}$ \\
\hline & April & Departure 3: Alva Stoll family returns to Aylmer \\
\hline & April & Departure 4: Joseph Stoll family returns to Aylmer \\
\hline & Sept & $\begin{array}{l}\text { Departure 5: Sammy Eicher family move to the New Order Amish } \\
\text { settlement at Belle Center, OH }\end{array}$ \\
\hline & Oct & $\begin{array}{l}\text { Family } 20 \text { / Wedding 6: Cristobal Irias and Rebecca Hochstetler (daughter } \\
\text { of Leroy); they remain in Honduras. This is the first marriage between a } \\
\text { convert and an ethnic Amish } \\
\text { Communion held at Guaimaca and San Marcos, for the first time separately }\end{array}$ \\
\hline & By fall & Bicycles permitted \\
\hline \multirow[t]{5}{*}{1978} & By June & $\begin{array}{l}\text { Tractors permitted } \\
\text { Departures 6, 7, and 8: Anna (Mrs. Peter) Stoll, the John Martin family, and } \\
\text { the Mark Stoll family move to Aylmer }\end{array}$ \\
\hline & Aug & Departures 9 and 10: Eric Kraly family and Lydia Mae Hochstetler leave \\
\hline & By Oct & $\begin{array}{l}\text { Departures } 11 \text { and 12: Ira Stoll and Abner Stoll families move back to } \\
\text { Aylmer, ON }\end{array}$ \\
\hline & Nov & $\begin{array}{l}\text { Departures } 13 \text { and 14: Monroe Hochstetler and Emil Helmuth families move } \\
\text { to the New Order Amish settlement at Salem, IN }\end{array}$ \\
\hline & Dec (circa) & Trucks are adopted, discontinuing affiliation with the New Order Amish \\
\hline
\end{tabular}




\section{Appendix 2: Family Relationships among Guaimaca Amish Settlers}

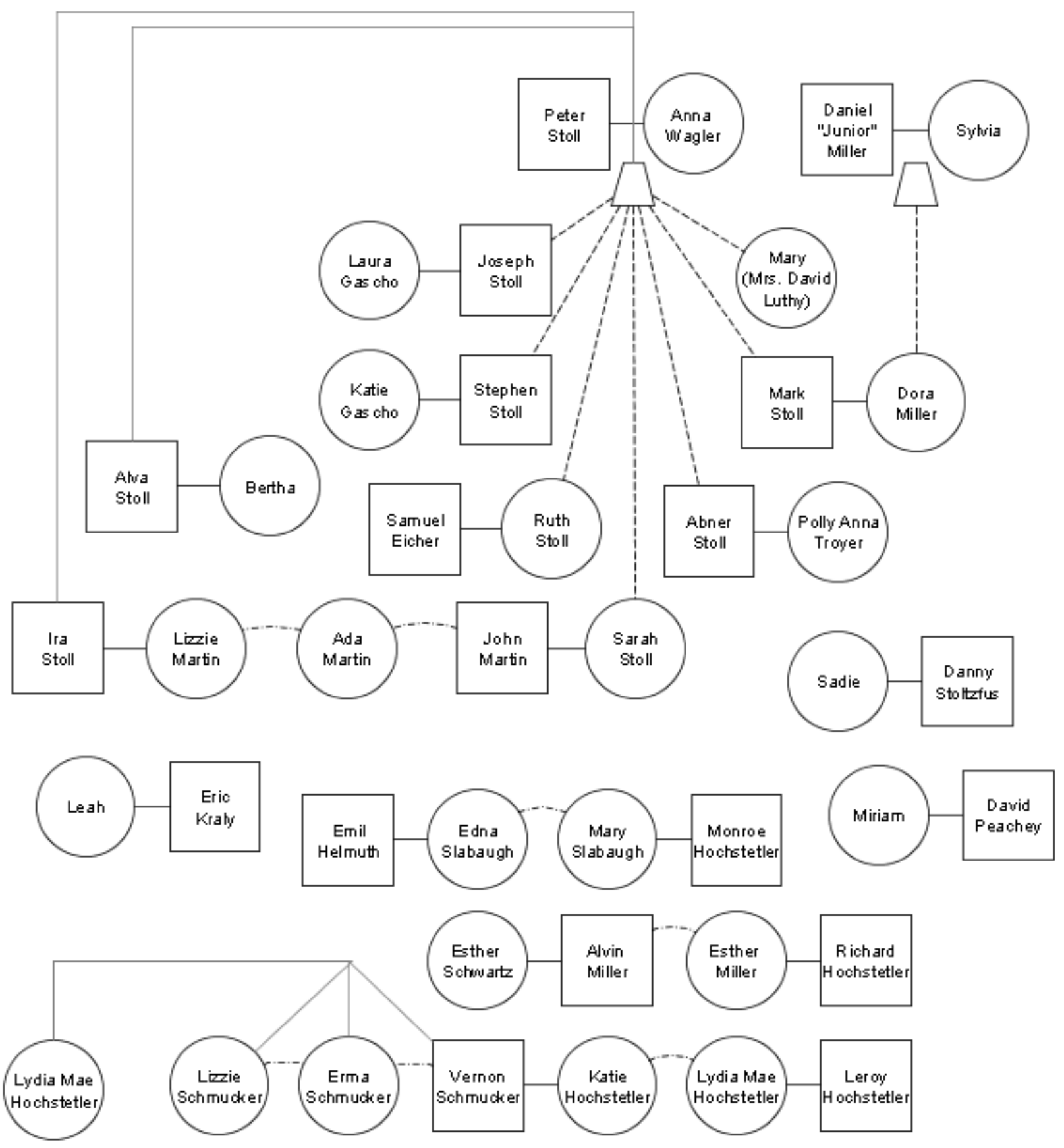

\begin{tabular}{|c|c|c|c|c|c|c|}
\hline $\begin{array}{l}\text { Ira } \\
\text { Stoll }\end{array}$ & $\begin{array}{l}\text { Male } \\
\text { (square) }\end{array}$ & & $\begin{array}{l}\text { Married } \\
\text { couple's } \\
\text { offspring } \\
\text { (hexagon) }\end{array}$ & Leah & $\begin{array}{l}\text { Eric } \\
\text { Kraty }\end{array}$ & $\begin{array}{l}\text { Marriage } \\
\text { relationship } \\
\text { (solid line) }\end{array}$ \\
\hline Kat & $\begin{array}{l}\text { Female } \\
\text { (circle) }\end{array}$ & $\left(\begin{array}{l}\text { Lydia Mae } \\
\text { Hochstetler }\end{array}\right)$ & $\begin{array}{l}\text { Cousin } \\
\text { relationship } \\
\text { (grey line) }\end{array}$ & $\begin{array}{l}\text { Alvin } \\
\text { Miller }\end{array}$ & Miller & $\begin{array}{l}\text { Sibling } \\
\text { relationship } \\
\text { (dotted line) }\end{array}$ \\
\hline
\end{tabular}

